\title{
ARQUITECTURA ASISTENCIAL E ICONOGRAFÍA HOSPITALARIA. USO Y FUNCIÓN DE UNA CASA-HOSPITAL DEL SIGLO XVI (I)
}

\author{
Jesús Pérez Morera* \\ Universidad de La Laguna
}

\begin{abstract}
Resumen
El exhaustivo y valioso conjunto documental asociado a la antigua casa-hospital de Nuestra Señora de los Dolores de la isla de La Palma permite conocer en detalle la función social y el régimen interno y sanitario de un establecimiento de este tipo (enfermedades, tratamientos curativos, medicación, dieta, higiene, personal hospitalario), no sólo como hospital, sino como casa de pobres y mendigos, cuna de expósitos y orfanato, manicomio, asilo, recogimiento de mujeres y prisión, además del perfil social de sus pacientes y acogidos. A estos fines respondía su organización arquitectónica y espacial, sus instalaciones y el papel teúrgico que cumplía la iconografía religiosa como método para soportar las enfermedades y lograr la protección divina en medio del dolor y las aflicciones corporales.

Palabras Clave: Hospital, arquitectura hospitalaria, enfermedades, medicación, indigencia, expósitos.
\end{abstract}

ASSISTANT ARCHITECTURE AND HOSPITAL ICONOGRAPHY.

USE AND FUNCTION OF A HOUSE-HOSPITAL OF THE XVI CENTURY (I)

\section{Abstract}

The exhaustive and valuable documentary set associated with the old house-hospital of Nuestra Señora de los Dolores on the island of La Palma allow us to Know in detail the social function and the internal and sanitary regime of an establishment of this tipe (diseases, curative treatments, medication, diet, higiene, hospital staff), not only as a hospital, but as a home for the poor and beggars, the cradle of foundlings and orphanage, mental hospital, asylum, women's seclusion and prison, as well as the social profile of their patients and caregivers. To these purposes responded its architectural and spatial organization, its facilities and the theurgic role that religious iconography fulfilled as a method to withstand diseases and achieve divine protection in the midst of pain and bodily afflictions.

KEYwORds: Hospital, hospital architecture, diseases, medication, indigence, foundlings. 
A lo largo de sus tres siglos de existencia (... 1512-1840), la antigua casa-hospital de la isla de La Palma generó un importante volumen documental. Cuentas, mandatos eclesiásticos, registros de enfermos, inventarios y relaciones de bienes muebles e inmuebles permiten reconstruir, a través de sus miles de folios, la práctica de la medicina y de la sanidad, el atendimiento a las capas más desfavorecidas y marginales de la población, las características arquitectónicas y funcionales del edificio y de las piezas que lo integraban y, en suma, la vida diaria y la historia cotidiana desarrolladas entre sus muros. ${ }^{1}$. Desde los primeros años del siglo Xvi, Santa Cruz de La Palma contó con una institución de beneficencia para ejercer la caridad con los pobres de toda la isla «y también con los muchos que navegando a las Indias, tocaban en aque-

* Doctor en Historia del Arte. Profesor titular en el Departamento de Historia del Arte y Filosofía de la Universidad de La Laguna. Edificio Departamental de Geografía e Historia, Campus de Guajara, s/n, San Cristóbal de La Laguna, 38071. Correo electrónico: jperezmo@ull.es.

${ }^{1}$ Para la realización de este trabajo hemos utilizado como principales fuentes documentales los materiales pertenecientes al archivo de la casa-hospital de Nuestra Señora de los Dolores de Santa Cruz de La Palma, custodiados desde el siglo XIX en el Archivo Municipal de Santa Cruz de La Palma [en adelante, AMSCP], en especial, el Libro primero de fundación de la casa Hospital con algunos documentos [legajo 629, n. ${ }^{\circ}$ 1] y el Libro de fundo y de Relaciones de esta Santa Casa Hobspital año de 1800 [legajo 629, n. ${ }^{\circ}$ 2]. Confeccionado durante la visita del obispo Francisco Martínez Ceniceros en 1603, el primero es un protocolo encuadernado en cuero que contiene el Libro de los Mandatos del hospital de Nuestra Señora de los Dolores desta ciudad de Santa Cruz en esta isla de La Palma [ff. 1 r.-56 v.], el Libro de inbentario a modo de libro de bezerro donde están en relación todos los tributos y rrentas del hospital de Nuestra Señora de los Dolores desta ciudad, con la tabla de misas y sufragios [ff. 58 r.-217 v.], y los inventarios de los «bienez muebles de la sachristía, enfermerías y lo demás del dicho Hospital»: inventario general (5 de septiembre de 1603), ff. 218 r.-250 v.; inventario general (30 de noviembre de 1618, ff. 252 v.-261 v.; inventario de lo que se entrega al sacristán (4 de noviembre de 1624), ff. 263 r.-263 v.; inventario de lo que se entrega al ama (26 de junio de 1632), ff. 264 r.-264 v.; inventario de lo que se entrega al mayordomo (8 de noviembre de 1644), ff. 268 r.-269 v.; inventario de lo que se entrega al sacristán (17 de junio de 1648), ff. 270 r.-275 r.; inventario de ropas y alhajas de la Virgen de la Concepción (13 de enero de 1643), ff. 277 r.-281 r.; inventario de alhajas de la misma imagen (19 de enero de 1655), ff. 282 r.-282 v.; inventario de lo que se entrega al sacristán (31 de marzo de 1650, ff. 284 r.-292 v.; inventario de lo que se entrega al ama (13 de enero de 1651), ff. 293 r.-293 v.; inventarios de la casa y enfermería (sin fecha y 9 de junio de 1657), ff. 294 r.-294 v. y 294 v.-295 r.; inventario del archivo (9 de septiembre de 1657), ff. 298 r.-299 v.; inventario de la iglesia, hospital y ropas y joyas de Nuestra Señora (30 de enero de 1673), ff. 300 r.-307 r.; inventario de la iglesia (3 de noviembre de 1699), ff. 308 r.-310 r.; y adiciones al inventario (30 de enero de 1711 y 7 de febrero de 1713), ff. 311 r.-314 r. Otra importante fuente de noticias es la serie de contabilidad integrada por los libros de cuentas de los mayordomos, el más antiguo de ellos, mandado hacer igualmente por el obispo Martínez, desde 1602 hasta 1649 [legajo 631, ff. 1 r.-577 v.]; desde 1650 hasta 1692 [legajo 632, ff. 1 r.-459 v.]; desde 1696 hasta 1705 [legajo 633, ff. 1 r.-385 r.]; desde 1705 hasta 1713 [legajo 634, ff. 1 r.-537 r.]; y desde 1738 hasta 1767 [legajo 635; ff, 1 r.-331 r.]. El legajo 328 contiene las cuentas sueltas de mayordomía desde 1738 hasta 1815. Los registros de enfermos abarcan desde 1674 hasta 1824 [legajo $649, \mathrm{n}^{\text {os }} .1$ y 2 , y legajo $650, \mathrm{n}^{\text {os }} .1$ y 2 ]. Un expediente existente en el Archivo Diocesano de Tenerife sobre el hospital de la isla de La Palma, con extractos de los mandatos dictados por los obispos y visitadores eclesiásticos que inspeccionaron la institución durante la segunda mitad del siglo Xvi, sirvió de base para el trabajo del investigador RoDRíguez Mesa, Manuel: «La vida hospitalaria en la isla de La Palma, a través de documentos eclesiásticos de la segunda mitad del siglo xvI», Estudios Canarios: Anuario del Instituto de Estudios Canarios, n. ${ }^{\circ}$ 45 (2000), pp. 425-438. 
lla ciudad $»^{2}$. Denominado primero hospital de la Misericordia, como consta de los testamentos de Juan Gutiérrez, sacador de aguas ${ }^{3}$, y del conquistador Vasco de Vaamonde $^{4}$, fechados respectivamente en 1512 y 1516, en virtud de la bula dada en San Pedro de Roma el 30 de junio de 1514 por el papa León X, «a ruego de los cathólicos Reyes don Fernando y doña Jhoana», fue puesto bajo la «adbocación de Nuestra Señora de los Dolores, a semejansa del de Tenerifes.'. En julio de 1553, los piratas franceses que saquearon la ciudad dieron fuego, según escribe el viajero portugués Gaspar Frutuoso, «al templo y casa de Nuestra Señora de los Dolores, que era hermoso, fresco y bien situado, con su claustro, ricas dependencias y enfermerías, donde se curaban diversas enfermedades; hospital bien asistido" ${ }^{6}$. Tres meses después, por escritura otorgada el 3 de octubre del mismo año ante Luis Maldonado, el hospital

${ }^{2}$ Viera y Clavijo, José de (1982): Noticias de la Historia General de las Islas Canarias, t. II, Santa Cruz de Tenerife, Goya, t. II, p. 701; véase también Lorenzo Rodríguez, Juan Bautista (1975): Noticias para la historia de La Palma, t. I, La Laguna, Instituto de Estudios Canarios, Santa Cruz de La Palma, Cabildo Insular de La Palma, pp. 140-141. Sobre los hospitales en Canarias, consúltense las referencias siguientes: Bosch Millares, Juan (1940): El Hospital de San Martín (estudio histórico desde su fundación hasta nuestros días), Las Palmas de Gran Canaria, Tipografía Minerva; Bosch MillaRES, Juan (1950): «Hospitales de Gran Canaria. El Hospital de San Lázaro», en El Museo Canario, n. ${ }^{\circ}$ 11, pp. 25-92; Espinosa de los Monteros y Moas, Eduardo (1982): «El hospital de Ycoden de los Vinos", en Homenaje a Alfonso Trujillo, t. I, Santa Cruz de Tenerife, Aula de Cultura de Tenerife, pp. 303-343; Alloza Moreno, Miguel Ángel y Rodríguez Mesa, Manuel (1984): Misericordia de la Vera Cruz en el beneficio de Taoro desde el siglo XVI, Santa Cruz de Tenerife, Gráficas Tenerife; Santana Pérez, Juan Manuel y Monzón Perdomo, María Eugenia (1995): Hospitales de La Laguna durante el siglo XVII, La Laguna, Ayuntamiento de La Laguna; González GonZÁLez, Orlando (1995): El hospital de Nuestra Señora de los Dolores de La Laguna: estudio histórico-artístico, La Laguna, Ayuntamiento de La Laguna; y Castro Molina, Francisco Javier (2012): Arquitectura y medicina en Canarias: dispositivos asistenciales y recursos sanitarios en Tenerife (siglos XV-XX), La Laguna: Universidad de La Laguna. Por lo que respecta al marco hospitalario de la isla de La Palma, véanse Pérez García, Jaime (1974): «El Sr. Díaz y su Plan General de Beneficencia», en Diario de Avisos (Santa Cruz de La Palma, 9 de mayo), p. 7; Arvelo Gil, Lourdes (1994): «Aproximación a la beneficencia en Canarias: casa cuna de Santa Cruz de La Palma», en X Coloquio de Historica Canario-Americana (1992), t. II, Las Palmas de Gran Canaria, Mancomunidad de Cabildos, pp. 1114-1130; Lово Cabrera, Manuel y Quintana Andrés, Pedro C. (1997): Población marginal en Santa Cruz de La Palma (1564-1700), Madrid, Ediciones La Palma; Quintana Andrés, Pedro C. y Lobo Cabrera, Manuel (1996): «Expósitos en la isla de La Palma», en Anuario de Estudios Atlánticos, n. ${ }^{\circ}$ 42, pp. 809884; Toledo Trujillo, Francisco Manuel y Hernández de Lorenzo Muñoz, Miguel (2001): Historia de la medicina palmera y sus protagonistas, Santa Cruz de Tenerife-Las Palmas de Gran Canaria, Centro de la Cultura Popular Canaria.

${ }^{3}$ Archivo Parroquial de El Salvador, Santa Cruz de La Palma [en adelante, APSSCP]: Capellanías, . $^{\circ} 214$, testamento de Juan Gutiérrez, sacador de aguas, natural de las montańas de la comarca de Vizcaya (2 de agosto de 1512), f. 3 v.: «Yten mando que de la dicha renta de las dichas tierras den en limosna al hospital de la Mysericordia desta billa de Santa Cruz otros dos myll maravedís».

${ }^{4}$ Archivo Histórico Provincial de Santa Cruz de Tenerife [en adelante, AHPT]: Conventos, 66-2 bis, testamento de Vasco de Vaamonde (28 de mayo de 1516), f. 16 v.: "Otrosí mandó a la obra del espital de la misericordia desta villa cien maravedís».

${ }^{5}$ AMSCP: Legajo 629, n. ${ }^{\circ}$ 1, libro de mandatos e inventarios, f. 40 r.

${ }^{6}$ Frutuoso, Gaspar (1964): Las islas Canarias (de «Saudades da Terra»). La Laguna, Instituto de Estudios Canarios, p. 116. 
compró a Juan Márquez, labrador, una enfermería por 120 doblas 7 . A su reconstrucción ayudaría el caballero flamenco Luis van de Walle el Viejo (†1587), que, según Viera y Clavijo, levantó a su costa el cuarto principal $^{8}$. En 1589, la institución de beneficencia se disponía a acometer construcciones de importancia, de modo que el obispo don Fernando Suárez de Figueroa alentó a hacer y acabar, habiendo comodidad para ello, "la obra del hospital». Con el objeto de que las enfermerías que estaban proyectadas se hiciesen «mejores y más sanas para los enfermos, conforme a las enfermedades que en ellas se obieren de curar", dio comisión al vicario de la isla y al médico del hospital para que fuesen fabricadas con arreglo a su parecer. Dos años más tarde se estaba finalizando la obra. Por entonces, el visitador Gabriel de Sarabia mandó concluir el cuarto nuevo y que se trajese el agua hasta el establecimiento por arcaduces de barro o canales de tea. Suponemos que este cuarto correspondía a la crujía hacia la calle de la Cuna, en la que se colocaría, entre 1599 y 1602, un balcón de madera de balaustres torneados cubierto de tejas. En agosto de 1798, otro incendio asoló la manzana situada entre la calle del hospital y la calle real. El siniestro afectó al edificio hospitalario y, según se detalla, fue necesario componer la lámpara de la iglesia, "que se rompió la noche del fuego», y las "fenestras que se quemaron», además de atender a dos pobres con las caras y las manos quemadas.

\section{UBICACIÓN Y CONSTRUCCIÓN}

La casa se ubicaba entre las llamadas calles «del hospital» y «de la cuna», actuales Pérez Volcán y Almirante Francisco Díaz Pimienta. La primera corría paralela a la fachada lateral de la iglesia y hacia la segunda se abría la fachada principal con la portería. Por el poniente lindaba con la casa y huerta de la familia Boot y Monteverde, después del mayorazgo de Fierro, levantada a principios del siglo XVII por el caballero flamenco Jerónimo Boot en los solares y sitios que había recibido en concepto de dote de sus suegros, Juan de Monteverde y doña Jerónima Cabeza de Vaca ${ }^{10}$, tras su casamiento en 1598 con doña Ana Monteverde ${ }^{11}$; mientras que por su parte meridional

7 AMSCP: Legajo 629, n. ${ }^{\circ}$ 1, libro de mandatos e inventarios, f. 179 r.

${ }^{8}$ No hemos podido confirmar esta afirmación de Viera y Clavijo, seguramente proporcionada por su informante, don José Van de Walle de Cervellón [Viera y Clavijo: op. cit., t. II, pp. 18 y 702]. Además de fundar una obra pía para casar huérfanas, Luis van de Walle el Viejo dejó en su testamento 20 doblas de limosna "para las obras y nescesidades de la casa y hospital de Nuestra Señora de los Dolores»; véase: Pérez Morera, Jesús (2004): «El convento dominico de San Miguel de La Palma después de la invasión francesa de 1553: discurso escatológico y contrarreformista", en Revista de Estudios Generales de la isla de La Palma, n. ${ }^{\circ}$ 0, pp. 267, 277 y 288.

${ }^{9}$ Cubierto con 2500 tejas, su hechura fue costeada por Francisco de las Muñecas.

${ }^{10}$ Entre 1599 y 1602 se pagaron 57 reales por reconstruir la pared que se había caído «entre doña Jerónima y la casa», así como levantar la pared que caía sobre el barranco.

${ }^{11}$ Pérez García, Jaime (2004): Santa Cruz de La Palma: recorrido histórico-social a través de su arquitectura doméstica. Santa Cruz de La Palma, Cabildo Insular de La Palma, Caja General de Ahorros de Canarias, Colegio de Arquitectos de Canarias (Demarcación de La Palma), p. 54. 
limitaba con el barranco de los Dolores, que dividía la ciudad en dos mitades y al que daba nombre. En la esquina, frente a la puerta de la iglesia, se hallaba uno de los tres puentes de madera que cruzaban la corriente. Conocido como el o la «puente del hospital», fue fabricado en 1642 con maderos de tea ${ }^{12}$. Por el lado del barranco, fue necesario construir y reforzar en diversas ocasiones $(1657,1671$ y 1692) un baluarte para defender el edificio de los embates y avenidas de las aguas ${ }^{13}$. Su ubicación, entre la corriente y la elevación conocida como el «lomo de Mataviejas», tampoco era la más conveniente para la aireación y el aislamiento necesario en un edificio de estas características. Esta fue una de las razones esgrimidas en 1822 por el párroco don Manuel Díaz para aconsejar su traslado al convento exclaustrado de Santa Clara, emplazado en lo alto de la población y al mismo tiempo en el borde del núcleo urbano: «Dicha casa-hospital está en el centro de esta ciudad, por un lado linda con un barranco cuyas corrientes impetuosas han puesto muchas veces en consternación a sus vecinos y por el otro tiene cortada la corriente de los vientos reinantes por pura elevación de terreno, tan considerable que a tiro de piedra ya está en triple a la que tiene la sobre dicha casa, tal es su localidad». A su mala situación se añadía además su simple y desarreglada fábrica:

Su construcción es todavía peor: dos salas, una sobre otra, la baja para hombres, la alta para mujeres, y dos piezas muy pequeńas para uncionarios con única salida a las mismas salas; éste es todo el hospital. Las piezas destinadas al servicio de la casa son pocas, pequeñas y mal cituadas, las altas en muy mal estado, las baxas con tal humedad que se han hecho inútiles. Por consiguiente, es fácil inferir que no puede haber limpieza en una casa como ésta y que no habiendo limpieza tampoco puede haber sanidad ${ }^{14}$.

Tras el traslado definitivo del hospital de Nuestra Señora de los Dolores al convento exclautrado de Santa Clara en 1840, el antiguo establecimiento fue ocupado por la Sociedad del Casino-Liceo de Santa Cruz de La Palma, que lo arrendó a razón de 45 reales de vellón mensuales. Sin el mantenimiento debido, la vieja casahospital se deterioró rápidamente; y en 1849 el salón principal, la habitación situada a su pie y el corredor que miraba al sur amenazaban ruina. Los peritos que efectuaron el reconocimiento del edificio encontraron todas y cada una de sus piezas muy dañadas, «pero principalmente las armaduras de la sala, el cuarto que queda a su cabeza y la antesala, cuyas tres piezas necesitan una pronta reparación, pues de otra manera sería inevitable la venida a tierra de esta última y la mayor parte de los techos de las dos primeras». Los frechales de la armadura de la antesala se hallaban diez pulgadas fuera de su plomo en el corredor del patio, con dos de los tirantes corrompidos por sus

${ }^{12}$ En ese año el mayordomo de la casa-hospital dio 200 reales a Juan Gutiérrez Calderón «para el ayuda de la puente que se hisso junto a el dicho hospital», mandados a pagar por auto del visitador Eugenio de Santa Cruz.

13 En 1671 se fabricó un baluarte «en el barranco quando quiso arruynar la casa». Para «la obra del baluarte» se hallaban mil reales en contado, en 1694-1695, en poder del licenciado Miguel Brito. En 1745-1746 fue necesario reparar de nuevo «el baluarte que descarnó el barranco».

${ }^{14}$ AMSCP: Legajo 773, n. ${ }^{\circ} 8$ (diciembre de 1822). 
extremidades, al igual que algunas de sus vigas o travetas; todas sus tablas de sollado hechas pedazos y enteramente inútiles y tres pilares y una porción de balaustres de la baranda del corredor desaparecidos. En la sala principal, la armadura estaba casi toda podrida y con riesgo de un inevitable desplome a causa de tener tres frechales, dos tirantes y una gran parte de sus tiseras rotas y podridas por sus encajes, de modo que se hacía forzoso abatir por completo su techo. La reparación de todo ello, con el cierre del corredor de la antesala con tabique y dos ventanas acristaladas, importó 296 pesos, según cuenta presentada en marzo de 1851 por los maestros carpinteros y albañiles a la junta directiva del Casino-Liceo ${ }^{15}$, que instaló en la sala alta (anterior enfermería de mujeres) uno de los dos pequeños teatros que funcionaban por entonces en la ciudad, mientras que la baja servía de casino ${ }^{16}$. Años después, en 1866, la iglesia anexa, abandonada y sin culto, fue cedida a la sociedad Terpsícore y Melpómene para sala de espectáculos y festejos públicos. Desacralizada y convertida en el actual «Teatro Chico», la intervención llevada a cabo a partir de ese momento ocultó por completo el anterior recinto religioso a través de una ligera estructura interior de madera y fundición ${ }^{17}$. En 1876, la corporación municipal acordó reformar el resto del recinto para destinarlo a plaza de mercado, uso que determinó su radical transformación. De 1879 data el proyecto de Luis B. Pereyra (1879), modificado en 1886 por el maestro de obras Felipe de Paz Pérez, bajo cuyas directrices se debió finalizar la actual «recova» o mercado a cubierto, con patio interior techado con una gran armadura de madera y crista ${ }^{18}$. Entre 1904-1906 se construyó por último la fachada hacia la calle Almirante Francisco Díaz Pimienta. De la antigua fábrica tan sólo perviven en la actualidad algunos puntuales testimonios: la pared medianera que separaba el traspatio de la casa-hospital de la del mayorazgo de Fierro, coronada por tres almenas, hoy semiempotradas en el edificio colindante; y quizás la estructura y los muros de carga de la crujía situada hacia la calle Almirante Francisco Díaz Pimienta, en la que hasta el siglo XIX estuvieron situadas la portería y las salas de las enfermerías alta y baja. En las hojas de madera de la puerta principal de esta última se recicló, como tabla de forro, una pieza de tea grabada con una inscripción sepulcral en capitales latinas, visible por su cara interior. Fechada el 26 de octubre de 1753, debió per-

${ }^{15}$ AMSCP: Legajo 663, n. ${ }^{\circ} 6$.

16 Lorenzo Rodríguez: op. cit., t. I, p. 141.

17 Fernández, Ángel Luis e Inglés Musoles, Fernando M. (1984): «Restauración y rehabilitación de dos teatros en Santa Cruz de La Palma», en El Teatro en Santa Cruz de La Palma: plaza de España, del 15 al 31 de octubre de 1984, Santa Cruz de La Palma, Ayuntamiento de Santa Cruz de La Palma, pp. 57-78; y Lorenzo Rodríguez: op. cit., t. I, p. 93: «En virtud de esta cesión, la expresada Sociedad hizo el Teatro en el mismo templo y sirviéndose de su mismo techo y paredes, si bien se le tapió la puerta que daba a la calle del Hospital y haciendo las reformas todas, de modo que no parece haber pertenecido al culto católico. En donde se hallaba el coro se colocó el escenario, y donde estaba el altar mayor se puso el pasillo o descanso y entrada principal del edificio. El paraíso se fundó contra el arto de la capilla mayor, que aún se ve allí».

${ }^{18}$ Hernández Rodríguez, María Candelaria (1992): Los maestros de obras en las Canarias Occidentales (1785-1940), Santa Cruz de Tenerife, Aula de Cultura de Tenerife, pp. 302-305. 
tenecer a la lauda sepulcral de don Jacob de Morales Figueroa ${ }^{19}$, fervoroso devoto de la imagen de Nuestra Señora de los Dolores, a quien el obispo fray Valentín Morán concedió licencia, el 20 de mayo de 1752, para fabricar un altar-retablo en el lado del evangelio de la iglesia del hospital ${ }^{20}$.

\section{FUNCIÓN SOCIAL DEL ESTABLECIMIENTO}

Además de curar a los enfermos, el hospital funcionaba como casa de acogida para pobres y mendigos de ambos sexos, tullidos, cojos y ciegos; cuna de expósitos y orfanato ${ }^{21}$, paritorio, asilo de ancianos, manicomio para dementes, refugio para retraídos y perseguidos por la Justicia ${ }^{22}$ y recogimiento de mujeres, varias de ellas recluidas en régimen de prisión ${ }^{23}$. En los fuertes días de invierno, de lluvia o de temporal, la casa-hospital abría sus puertas para ofrecer a los pobres, mendigos e indigentes un techo donde resguardarse y un plato de puchero caliente según «costumbre» $\mathrm{o}$ «estilo» ${ }^{24}$.

\section{Casa de Recogimiento}

A las viudas, solteras y mozas libres, huérfanas, «hijas de la cuna» $\mathrm{o}$ «hijas de la casa» se les permitía quedarse en el establecimiento recogidas como mendigas, caso de una mujer de Garafía de 74 años y de otra mujer de la ciudad, Ana la Coja, viuda de 44 años, que entraron en 1674 y permanecieron en el hospital sin que la institución corriese con su manutención. Tras su recuperación, los pobres indigentes volvían a pedir limosna en la calle, mientras «asistían» en la casa ayudando en los quehaceres cotidianos ${ }^{25}$. Dentro de sus muros parió en 1644 una moza que había sido expulsada de su casa por su padre, a la que se atendió con la carne de

19 Dice así: «POSTERoru[M] / JACOBI MORALES / VITA FUNCTI / VII CALENDAS NOVEM[BR I[s] / MDCCLII[I]». Agradecemos el dato a Víctor J. Hernández Correa, del Servicio de Patrimonio Histórico del Ayuntamiento de Santa Cruz de La Palma.

20 Archivo General de La Palma [en adelante, AGP]: Fondo de Protocolos Notariales [en adelante, PN], Escribanía de Pedro de Escobar y Vázquez, caja n. ${ }^{\circ} 18$ (9 de noviembre de 1757), f. 314 v.

21 Durante los años 1668-1669 el hospital corrió con los gastos de la alimentación de una «nieta del ama de la casa, que se a criado en ella de caridad por ser pobrísima y guérfana».

22 En 1602-1603 «vn retraído que está en el dicho hospital» dio una limosna de 1440 maravedís.

23 En 1672 se encontraba presa en el hospital María de Tinisara, a quien se le regalaron un jubón de gordalate, dos camisas de coleta y un par de zapatos por asistir como «ama de leche».

24 En 1756-1757 se gastaron cuatro reales «con los pobres recojidos dos días que no pudieron salir con las llubias" y otros dos reales en 1802 en "conducto para cinco recojidos en día de llubia".

25 De 80 años de edad, Simón García ingresó enfermo el 7 de julio de 1693, volviendo a pedir en la calle desde principios de septiembre. Asistía en la casa y falleció un año después. En la misma fecha entró Francisca Hernández, de más de 60 años. Tras ser dada de alta el 15 de julio, «volvió a asistir en la casa para buscar su limosna en la calle». 
una gallina. Con orden del juez, en 1693 entró a sustentarse, a causa de su «necesidad estrema», Pascuala, moza, con su hijo Hipólito, al que había propinado una paliza y que murió al cabo de mes y medio. Por igual disposición, ingresaron en ese año Beatriz González, vecina de Tazacorte, de más de 75 años, que colaboró en las tareas de la casa mientras mejoraba de sus dolencias; y Francisca, moza de Los Galguitos, en régimen de prisión, a la que se alimentó durante los meses siguientes por sus buenos servicios y estar el ama enferma. También se daba asistencia a mujeres indigentes embarazadas para evitar que, por su miseria, echasen las criaturas en el torno, en perjuicio del hospital. Así se hizo en 1669 con dos «mujeres preñadas».

\section{Hospital MiLITAR}

En diversas ocasiones, el establecimiento sirvió además como hospital militar durante los ataques, incursiones o intentos de invasión que sufrió la isla, como un irlandés y cuatro milicianos de Tazacorte y Tajuya, el primero herido por los españoles y los segundos por los ingleses, que entraron entre el 29 y el 31 de diciembre de 1740, saliendo a los pocos días ${ }^{26}$. En 1775 y 1777 ingresaron varios soldados del destacamento y «regimiento de Canaria» y del "presidio de esta isla». Entre los años de 1797 y 1803, coincidiendo con la guerra anglo-española (1796-1802), fueron hospitalizados medio centenar de combatientes pertenecientes a la bandera del regimiento de La Habana (1795-1803), al destacamento de «tropa viva» (1797-1800), al «regimiento de blanquillos» (1801-1803) y a la segunda compañía del regimiento de Vitoria (1801), soldados, dos tambores, un pito, un sargento y un cabo principal con síntomas de fiebres tercianas, "siurgia» o sífilis ("gálico»); entre los que habría que incluir al numeroso grupo de 16 franceses curados entre 1797 y 1805, con un cabo y un soldado del batallón de infantería ${ }^{27}$; y cinco ingleses, tres en mayo de 1798 y dos en enero de 1806.

26 Sobre este ataque, véase Poggio Capote, Manuel (2014): «La isla de La Palma en la Guerra de la Oreja: El ataque a Puerto Naos de 1740», en Anuario de Estudios Atlánticos, n. ${ }^{\circ}$ 60, pp. 291-355.

27 Antonio Barsat, que ingresó dos veces, en mayo de 1797 y en septiembre del mismo año; Juan Bautista Canara, en julio y en octubre de 1797; Juan Francisco Roda, en octubre de 1797; Pedro de la Fee, en noviembre 1797; Pedro Ros, en abril de 1798; Miguel Piñon, Pedro Morín y Antonio Calderón, en mayo 1798; Juan Bautista Linón, en septiembre de 1799; Santiago Luis Germian, Joseph Vicente y Vicente Loris, en diciembre de 1799; don Pedro Esteban Funtano, ayudante, y Luis Blino, cabo de batallón, en agosto de 1800; Francisco Cádiz, soldado del batallón de infantería, de 22 años, natural de París, "gálico», en diciembre de 1802; y Juan Juri, natural de Aue de Gracia, de 32 años, de «siurgia», en junio de 1805 . 


\section{Cuna de EXPósitos}

Para la lactancia de los recién nacidos echados en el torno de la casa-hospital, así como para su manutención mientras no hubiese quien los proahijase ${ }^{28}$, se estableció una cuna de expósitos, cuyo origen era casi tan antiguo como el del propio establecimiento. Según el informe que suscribieron en 1784 don Diego Vargas Machuca y el irlandés don Dionisio O’Daly, hermanos de la Junta de Caridad, su mortalidad era más elevada que en otras cunas. De los 30 niños que regularmente caían en la casa al año, fallecían del orden de cuatro a seis en los primeros meses, «quando los calculadores políticos de la Europa sienten corresponder el número de 6 a 8 en 100, de ocho meses abajo ${ }^{29}$. A ellos había que sumar el crecido número de los que morían después de proahijados por la indigencia de sus nuevos padres. El tiempo de lactancia era comúnmente de 12 meses, con la excepción de los que no sobrevivían o los que, por su "desmedrado» estado y «falta de dentadura», se les aumentaba por algunos meses más. Este periodo resultaba a todas luces insuficiente, «atendidas las circunstancias del país y mantenimiento de la maior parte de sus naturales, de que las 6 octavas partes es bien sauido se nutren $\mathrm{u}$, por mejor decir, conservan la vida, con la raíz del helecho, que en otros parages y payces desconocen aún los mismos cerdos». Para asegurar su supervivencia, se hacía preciso prolongar su nutrición al menos hasta los 18 meses, «siendo así que la regla común en las casas, aún menos acomodadas del paiz, estiende la lactación de los hijos a dos años». Repartidos por toda la isla, los lugares de campo donde se criaban, cercanos a las cumbres, obligaban a proporcionarles algún vestuario para resguardarlos de los fríos y no dejarlos a las inclemencias del tiempo, "como sucede en el día, que solo se contribuie a cada ama que lleva un expósito con 4 reales plata para comprarle una o dos camisitas, que quanto más pueden ser de coleta, que es lo mismo que cilicio para estos tiernos inocentes, destituidos de faxas etc». Después de los 12 meses, los niños volvían al hospital en tan malas condiciones que pocos sujetos acomodados querían hacerse cargo de ellos, razón por la que sólo se encontraban personas infelices, sin que se pudiera evitar su entrega «por baja y desacomodada que esté su esfera, resultando, por concequencia natural, participar el adoptado en todo de la crianza y miseria del adoptante». Consideraban los citados hermanos que la casa necesitaba unos ingresos de al menos unos 1096 pesos al año (cantidad muy superior a los 355 pesos que se gastaban por entonces) para mantener a unos 30 expósitos, vidas que, quizás conservadas, podrían transformarse en útiles vasallos, «como lo han sido muchos de los criados en esta cuna, que han llegado a merecer lugar en los estados más respectables del sacerdocio, medicina y leyes, como hai algunos en

${ }^{28}$ AMSCP: Legajo 611, n. ${ }^{\circ} 897$, noticias sobre establecimientos piadosos, memorias y fundaciones (1 de junio de 1837).

${ }^{29}$ Entre agosto de 1807 y febrero de 1810 cayeron en el torno 111 expósitos; de ellos 50 murieron y otros 61 salieron criados de diversas edades «porque el estado de debilidad en que nacían y el poco cuidado de algunas nutricias en alimentarlos exigía en muchos más de un año de leche y en algunos hasta año y medio y aún dos años». 
el día, fuera de muchos otros exparcidos en estos campos y de no podo respeto en ellos». La escasez y precariedad de sus rentas y la inmediatez y urgencia de sus gastos convirtieron a la cuna de expósitos -según los mismos caballeros- en la "piedra de toque de la pasiencia y sufrimiento de los mayordomos y lo que más retraía a los más piadosos a admitir la administración de la casa-hospital ${ }^{30}$. Tal obra de caridad consumía buena parte de los recursos económicos del establecimiento y no faltaron visitadores eclesiásticos que prohibieron mantener a más niños, como el licenciado Pedro del Castillo en 1580. Ello llevó al obispo don Francisco Martínez, en los mandatos que promulgó en 1603, a hacer la siguiente reflexión:

El gasto que el dicho hospital tiene con los niños expósitos es mui grande y dificultoso el rremedio, porque si se da en serrar la puerta para no resibirlos se puede temer que las madres hagan algún desatino o echándolos en la mar o en otra parte donde no parescan que sería grande offensa de Nuestro Señor y ssi se abre la puerta enteramente a todos lo que echaren serán tantos que no lo pueda sustentar el dicho hospital y le sea forsoso faltar a la cura de los pobres, ques su prinçipal intento.

Para evitarlo, el prelado aconsejaba que el mayordomo averiguase secretamente el origen de las criaturas:

Y, si hallare ques de alguna muger tenida por donçella o de alguna cassada que esté ausente su marido, procurará que se críe a costa del dicho hospital, guardando todo secreto porque la honrra de las dichas no padesca, que sería grande inconbeniente, y si hallare ques de alguna muger soltera, negra o mulata o persona cuya onrra no pueda padecer, se le procure bolber y haser que le críe ${ }^{31}$.

La cifra de lactantes aumentó rápidamente a lo largo del siglo XVII. En 1602 echaron sólo a cuatro (María de Pascua, Anica, Juanico y María, además de Esperancica, a la que se le "halló a su madre y se le dio»), que fueron criados por varias mujeres, casadas y solteras, a 12, 13 y 14 reales cada mes, según sus circunstancias particulares, fuera de la ropa que se les hizo para vestirlos. Cinco amas de cría se mencionan en 1603 por amamantar a otros tantos nińos. En 1616-1617 constan 16 niños, a 15 reales cada mes; 17 en 1618-1619, 25 en 1619-1620 y 41 en 1623-1624 «echados a la puerta de el hospital», aparte de los que habían quedado del mayordomo anterior. En la centuria siguiente, según aseguraron al capitán de navío Varela y Ulloa "personas de muchos crédito" (1789), en algunos años los expósitos bautizados superaron en número a los de legítimo matrimonio, sin embargo de lo cual se había «atendido siempre a la criansa de todos porque los particulares de La Palma se presentan voluntariamente a sacar del hospital a los niños para criarlos, educar-

30 AMSCP: Legajo 328, informe dirigido por los hermanos don Diego Vargas Machuca y don Dionisio O'Daly a don Miguel Mariano de Toledo, gobernador eclesiástico (24 de noviembre de 1784).

31 AMSCP: Legajo 629, n. ${ }^{\circ}$, libro de mandatos e inventarios (3 de septiembre de 1603), niños expósitos, ff. 32 r.-32 v. 
los y darles destino con que puedan subsistir ${ }^{32}$. En 1643 se siguió proceso a causa de un recién nacido que había sido expuesto a las puertas del consistorio municipal. El cabildo alegó que no tenía obligación de criarlo y que debía ser recibido por la casa-hospital, tal y como ordenó el vicario de la isla. A ello se opuso el mayordomo del establecimiento, arguyendo que la casa no tenía renta particular para ello y que sólo se hacía por caridad en detrimento de los pobres y de su curación. Visto por el provisor, sentenció que el hospital no tenía más obligación que criar «a los que se expussieren a sus puertas y los que se expusieren a otras a de ser obligado el juez que fuere de esta ysla a pedir limosna para la criación $»^{33}$. Los niños eran echados en el torno desnudos o con «ropita», aunque, por lo común, el hospital se hacía cargo de su vestuario ${ }^{34}$. En caso de muerte, las amas de cría devolvían la ropa para ser usada o repartida entre otros niños; también podían quedarse con ella como premio a su trabajo.

Residentes en el campo, especialmente en los lugares más cercanos a la ciudad (Mazo, Las Breñas, «La Banda» o valle de Aridane, Puntallana, Los Sauces) o en los barrios más pobres de la población (Jorós, San Sebastián, San Telmo, La Somada), las amas de cría eran mujeres de humilde condición, entre las que se cuentan casadas $\mathrm{y}$ «mujeres libres», viudas, criadas y libertas (Catalina Rodríguez, mujer de "Cachafiz», de la Breña; María Pérez la Gata; Beatriz Hernández, «muger del Cambado»; la hija de la «vieja Beatriz Hernández, de Jorós»; Beatriz Pérez la Cambada; María Francisca la Ratona; Catalina Rodríguez, «hermana del yndiano»; María Hernández la Chiquita, tabernera; «una hija de la Liria, de la otra vanda»; María la Regañada...). Las había de color, como la negra Ana de Escobar, que dio el pecho a una niña llamada María durante un mes y 21 días en 1634-1636. De color pardo eran Javiera y la hija del mulato Jorge, que criaron a María, Catalina y a Tomás entre 1738 y 1745 . En los casos en los que los niños no recibían el debido atendimiento, el mayordomo podía arrebatárselos para dárselos a otras. Así lo hizo en 1643 el capitán Jacobo Monteverde y Brier con Catalina Xuárez, vecina de Mazo. Tras amamantar a lo largo de 13 meses al mulato Juan, el administrador del hospital se lo quitó, «por mal criado», para entregarlo a Lucía Francisca, mujer de Melchor de León, «quien lo acauó de criar el año y medio y lo trajo a la casa para mí», sin duda para servir de esclavo ${ }^{35}$. En 1768, el mayordomo, previa consulta con el médico de la casa, se negó a pagar cosa alguna a María Lorenzo, de Tijarafe, por haber traído un niño completamente desnudo y "muriéndose en mi presencia de flaquesa»; al igual que el resto del dinero que faltaba para el complemento del año a Josepha María Mar-

${ }^{32}$ Museo Naval, Madrid: Derrotero y Descripción de las Islas Canarias (1788-1789), Ms. 511, f. $70 v$.

33 AMSCP: Legajo 629, n. ${ }^{\circ} 2$, libro de relaciones, f. 163 r.

34 Como medida de prevención, en 1796 se hicieron dos camisas de lienzo para los nińos que echaban desnudos en el torno.

${ }^{35}$ En diciembre de 1708, Catalina Pérez, mujer de Sebastián Pérez Ojitos, devolvió a la casa (donde murió), ya enferma, a Gabriela, "mal criada y sin ropa», a pesar de haber recibido 15 reales para vestirla, razón por la que no se le pagó el resto de su crianza. 
tín, mujer de Pedro Phelipe, de Barlovento, que había criado a un niño «mui desmedrado» (fallecido poco después), cuya vida corría peligro, según dictamen del médico, por haber mamado leche durante todo su preńado. Los mayordomos acudían además a la Justicia para lograr identificar a las madres y devolverles las criaturas que habían parido. En 1769, se pagó a dos ministros reales por ir a buscar, por orden del juez, a Sebastiana Rola, de Pajares (Los Sauces), que tras haber alumbrado a un niño y «baptisádolo en la pila de Monserrate y dádole pecho 15 o 20 días, a vista y siencia de todo el pueblo, lo trajo al torno de la cassa hospital»; y a Teresa González, hija de María de Jacob, de La Dichosa (Las Manchas), que había dado a luz a una nińa a la que bautizó y puso por nombre María de la Encarnación, «cuyo preñado y parto fue público en su vesindad». A veces las madres solteras recuperaban a sus hijos tras contraer matrimonio. Dado a criar en 1680 a Melchora Camacha, vecina de Tiguerote, el niño llamado Gabriel «se volvió a su madre porque se casó con el moso». El día en el que habían sido expuestos, la «ropita» que vestían y otras marcas o señales servían para identificarlos en estos casos.

Los padres adoptivos podían ser esposos que no habían «tenido hijos de su matrimonio", como Francisco Álvarez Barreto, zapatero, que proahijó en 1768 a una expósita; campesinos y artesanos de diferentes oficios (carpinteros, albañiles, cereros, barberos), clérigos y licenciados, miembros de profesiones liberales, mayordomos de la casa y amas de cría que se quedaban los niños después de destetados o alguna persona de clase noble, como doña María de las Nieves Massieu y Fierro, hija del coronel don Felipe Manuel Massieu de Vandale, a quien se entregó un niño en 1768; o del presbítero don Ambrosio Arturo, quien, al igual que otras personas, contribuyó con sus limosnas a la crianza de los expósitos «por pretender para sí los niños». Soltera y posible madre natural de don Fernando de Castilla ${ }^{36}$, doña Beatriz de Miranda se llevó a una niña (quizás su hija) en 1647 tras haber sido amamantada durante tres meses por Águeda Leal, vecina de Mazo, mujer de Lucas Sánchez. Entre 1657 y 1666 se dieron diferentes niños y niñas a "las Bocarras de San Telmo", a "las Caravallitas», a "las Chicharras», a las monjas del convento de religiosas dominicas, al licenciado Carlos de Robles y Prados, a los presbíteros Gaspar de Silva y Barros y Cristóbal de Acosta, organista de la iglesia del hospital, a doña Isabel de Fraga, a numerosas mujeres u hombres casados, a dos amas de cría que se quedaron con ellos... Expuesto el 3 de enero de 1666, el niño Blas fue adoptado por el carpintero Sebastián Rodríguez de las Vacas. Autor del paso de la «Oración del Huerto» (1664), en sus últimas voluntades, otorgadas quince años después, dejó todos sus bienes a sus tres hijos legítimos y la herramienta de su oficio a su hijo adoptivo para que se procurase la vida ${ }^{37}$.

\footnotetext{
36 Pérez García: op. cit., p. 51.

37 AGP: PN, Escribanía de Andrés de Huerta (22 de febrero de 1681), f. 90.
} 


\section{INGRESOS, ORIGEN GEOGRÁFICO Y PERFIL SOCIAL DE LOS HOSPITALIZADOS}

Los pacientes entraban para curarse de sus enfermedades, para recibir unciones (un 34\% en 1810-1811) o, por su avanzada edad, para ser atendidos en sus últimos momentos. Con edades comprendidas entre uno y doce años, los niños ingresaban por lo común para recibir unciones o para ser criados a falta de padres adoptivos que los proahijasen. Las hospitalizaciones podían incluir a varios miembros de la unidad familiar, sobre todo a la madre con alguno o algunos de sus hijos. Por cuenta del obispo García Ximénez fueron acogidos en la casa en 1676 María Gutiérrez con su hija de siete años, naturales de la isla de El Hierro, y un matrimonio de la isla de La Gomera, con sus dos hijos de tres y dos años, de los que sobrevivió el padre y la mayor de las criaturas. María de la Encarnación, fallecida al cabo de tres meses de su ingreso, dejó a su muerte otro hijo párvulo, de cuya crianza se responsabilizó la casa-hospital en agosto de 1776. El tiempo de hospitalización no solía sólo ser demasiado largo, a lo sumo dos o tres meses. Con frecuencia, los pacientes se internaban varias veces por cortos intervalos. Enfermo de «necesidad», el 1 de enero de 1803 lo hizo Andrés de la Concepción. Viudo de 77 años y sepulturero de oficio, salió dos días después. Por «hanbre y bejes», fue acogido de nuevo en la casa desde el 19 de agosto hasta el 30 de septiembre y desde el 18 de octubre hasta el 9 de noviembre, fecha de su muerte.

\section{ORIGEN Y PROCEDENCIA: NATURALES Y EXTRANJEROS}

Además de enfermos del conjunto de la isla, el hospital atendió a hombres y mujeres de todas las demás sin excepción, de La Gomera y El Hierro, de Tenerife, Gran Canaria y Fuerteventura y especialmente de Lanzarote. Por cuenta del obispo García Ximénez, se internó a una quincena de enfermos y mendigos en 1675-1676, entre ellos un hombre de 46 años y una mujer de La Gomera que fueron a la Fuente Santa, de la que regresaron pasados quince días. Los volcanes que asolaron a Lanzarote en 1730-1736 fueron causa de la llegada de varios enfermos. Tal afluencia fue constante en el último tercio del siglo XviII y a lo largo de las primeras décadas de la centuria siguiente, pacientes de ambos sexos que ingresaron casi siempre para tomar una unción. A ellos hay que agregar marineros, navegantes y originarios de otras ciudades portuarias como Santa Cruz de Tenerife y Garachico, portugueses del Brasil y de los archipiélagos de Azores, Madeira y Cabo Verde, gaditanos, ingleses, franceses y holandeses, tripulantes o pasajeros de los navíos que habitualmente recalaban en Santa Cruz de La Palma. Entre los franceses que entraron en 1679 se cuentan cuatro varones de 18, 20, 22 y 25 años y dos mujeres, Marisiene y Cathalina Simone, de 20 y 22 ańos, naturales de París, Lisieu y Nantes. Todos ellos sanaron, salvo el joven Luis Banon, que aunque era «hereje se reduxo a la fe chatolica romana», confesando, comulgando y recibiendo la extremaunción antes de morir. Por el contrario, en 1682 no se le administraron los sacramentos al holandés Alberto "por ser herege». A finales del siglo XviII y principios de la siguiente centuria, durante 
la guerra anglo-española de 1796-1802, se recibió a holandeses, venecianos, genoveses, portugueses y chinos, además de numerosos españoles: andaluces en primer lugar (8), gaditanos del puerto de Cádiz (6), un carpintero de rivera de Sanlúcar (1) y un cordobés (1); valencianos (4), catalanes (1), mallorquines (1), gallegos (3) y vas$\cos (2)$. En esos ańos aparece un grupo de chinos, seguramente marineros: Marcelo Nacreto, «natural y vecino de la China», que entró en julio de 1798; Benito Choa y Reimundo Carrosa, ambos el 12 de febrero de 1799; Juan Francisco, uncionado en octubre de 1799; y Luis Mirán, "natural y vecino de la ciudad de la China», marinero soltero de 25 años que ingresó dos veces en octubre de 1803.

\section{Protocolo DE INGRESO}

A partir de 1674 el hospital comenzó a llevar un libro de entrada y salida de los pacientes. Hasta entonces, los únicos registros eran los que cada mayordomo asentaba en los cuadernos por los que daba las cuentas, sin que pasasen de unos a otros. Ante su falta, el licenciado don Juan Pinto de Guisla, visitador general de la isla de La Palma, dispuso la apertura del primer libro de enfermos ${ }^{38}$ para tener el «orden conveniente». En él se daría cuenta y razón para que «conste en todo tiempo, de los enfermos que se curan y de los que salen del hospital o mueren en él», con indicación del nombre de cada uno en capítulo distinto, vecindad y naturaleza, día, mes y ańo de entrada, y «si reciuieren los sacramentos como lo deuen hazer para curarse». De acuerdo a las constituciones sinodales, todos los pacientes debían confesar y recibir la comunión en el momento de su ingreso (en caso de especial gravedad, también se les daba la extremaunción). Con la creación de la Junta de Caridad en 1782, se estableció un protocolo de entrada, recogido en sus constituciones, que preveía que los pobres que pretendiesen venir al hospital darían primero memoria a la junta. Acto seguido, el médico reconocería la enfermedad y expediría certificación con juramento, tras lo cual irían dos hermanos para comprobar su indigencia $y$, si efectivamente era cierto, conducirlo al hospital, «dexando el mayordomo anotado en su libro el día en que entra, como también los dos hermanos informarán a la junta el juicio que formaron de su pobresa». El tiempo y modo de despedirlos se disponía en el capítulo xIII de las constituciones:

Al pobre no se le despedirá, ni se le permitirá salir hasta no estar perfectamente curado; y esto lo ha de desir el médico, dándole tiempo para la combalesencia. Se le entregará toda la ropa que aya lleuado y se apuntará el día de su salida. Si acontesiese la muerte, se le enterrará como es costumbre y se pondrá la partida de su muerte, y entierro en el libro que para esto habrá en el hospital. Y a estos entierros asistirán los

38 AMSCP: Legajo 649, n. ${ }^{\circ}$ 1, libro de enfermos del hospital de Nuestra Señora de los Dolores de esta ciudad de La Palma que comiença desde principio del año de mil y seiscientos y setenta y quatro, MANDAdo haCer POR El LiCenciado don Juan Pinto de Guisla. 
hermanos para exerser su caridad hasta el sepulcro con aquellos que se han acogido a la santa cassa del hospital ${ }^{39}$.

Cumpliendo con este protocolo, en junta extraordinaria del 7 de abril del año siguiente, se leyó el memorial de María Tabares, que pretendía recogerse en la casa «para parir y después curarse»; y el de José de la Cruz, que ya había estado previamente. Temido por las amas por su mala conducta, según la certificación del médico no había logrado la salud por sus «exesos y desarreglos», y aún había alborotado la casa. En vista de ello, se acordó franquearle los medicamentos y manutención dentro del establecimiento, siempre que el alcalde mayor pusiese dos guardas para custodiarlo, asegurar su restablecimiento y la quietud de la institución ${ }^{40}$. En el momento de su entrada se tomaba nota de la ropa de vestir (camisas, calzones, chupas, capas y sombreros en el caso de los hombres; enaguas, camisas, becas, tocas, manto y saya, en el de las mujeres), así como de las sábanas y camas que, eventualmente, podían traer consigo. Con una enagua de sarga verde y dos camisas usadas, una beca y una toca ingresó en diciembre de 1737 Francisca Gómez de Paz, vecina de San Andrés, cuyo padre se obligó a pagar al hospital 50 reales "por todo el verano del año que bendrá de $1738 »^{41}$. Si el paciente moría, la ropa del difunto se repartía entre otros pobres, se daba a las amas y criadas de la casa como pago a sus servicios o se aplicaba en misas por su alma. En 1602, el mayordomo Melchor García de Segura se hizo cargo de los maravedís que importaron los bienes de Bernardino, de color negro, e Isabel de Herrera, y del valor de la ropa de Francisca Benítez y Nicolás González, "que mató el mulato del doctor Medel», todos ellos fallecidos en la casa. En los años siguientes figuran el capotillo y el sayo de un hombre que murió en el hospital y se vendió; la ropa que dejaron un negro de Cabo Verde (1603), Juan de Acevedo, natural de Canaria, Francisco Benítez, portugués, y la de «fulano de Mederos» (1624-1626); el ferreguelo, el calzón y la ropilla vieja del portugués Francisco Rodríguez (1634-1636); la saya de "Juana la negra», que se dio al ama (1639); el calzón y el jubón de «gordalate muy usado» que quedó de un pobre, y los dos «sayos de paño canario» de dos pobres con los que se vistió a otros dos (1668-1669). Cuatro reales y un cuarto se encontraron en el sombrero de un forastero fallecido en 1634-1636. En 17 reales y 24 maravedís se apreciaron los botones de plata que pertenecieron a Domingo de Ramos, natural de Canaria (1738); mientras que el

39 AMSCP: Legajo 733, libro 1. ${ }^{\circ}$ de la Junta de Caridad, ff. 6 r.-6 v.

40 Idem: (7 de abril de 1783), f. 23 r.

${ }^{41}$ Entre noviembre de 1737 y marzo de 1738, entraron en la casa-hospital varios pacientes con la siguiente ropa de vestir y de cama: Bernardo Rodríguez (vecino de Los Sauces), con camisa, calzones, chupa, capa de baeta y sombrero; Margarita de Betancor (vecina de Velhoco), con manto y saya, beca, dos pares de enaguas azules de sarga, camisa y enaguas blancas, dos tocas, un jubón blanco y dos sábanas de lienzo casero; María Petronila, con enaguas de calimanco, beca, camisa, toca y pańuelo; María Trinidad (de la ciudad), con cama, camisa, enaguas blancas, justillo, gasa de toca, manto y saya; Margarita de los Reyes, con dos sábanas, una colcha, enaguas de sarga, camisa, dos tocas y enaguas blancas; y María de las Nieves (de San Andrés), con dos pares de enaguas, dos camisas, dos tocas y tres libras de hilado. 
manto y saya del ama María Farias y tres enaguas de tres mujeres pobres sumaron 72 reales y 24 maravedís (1738-1745). Otros 20 reales dieron al mayordomo por las enaguas de lamparilla de María Casaño (1756-1757); cinco reales por «una chaquetita que quedó de un orchillero" y 65 por un poco de ropa de Tiburcia Guanche, "pobre que murió en dicha casa" (1761-1764). Con los enfermos contagiosos o héticos", se procedía a quemar la ropa para evitar infecciones.

\section{Gastos de Curación}

Aunque no parece que fuera común, los pacientes podían contribuir a los gastos de su atendimiento con una cantidad pactada o con su salario. En septiembre de 1693, por ejemplo, Juan Pérez, curtidor, ajustó entregar cien reales por los medicamentos y alimentos que necesitase, compromiso u obligación que fue ratificado ante el escribano Andrés de Huerta. Así sucedía con los militares. Baltasar de Morales, uno de los doce soldados del rey, con más de 70 ańos de edad, aportó la mitad del sueldo de su plaza "porque la otra mitad se da a quien suple las velas». 323 reales recibió el mayordomo por los alimentos y medicamentos de seis miembros del destacamento de la isla que se curaron entre 1774 y 1779; y otros 26 tostones en 1800 por la hospitalidad de tres soldados. A razón de un tostón al día, «según le pasa el rey», pagó en 1796 el sargento de la cuarta compañía por Domingo Rodríguez, cantidad equivalente a la que había satisfecho un año antes otro soldado del regimiento de La Habana durante su convalecencia. Según reflejan las cuentas, las retribuciones por la «hospitalidad» se hicieron más comunes desde finales del siglo XviII ${ }^{42}$. El agradecimiento por haber recobrado la salud también movía a los pacientes y a sus familiares a colaborar con el mantenimiento del establecimiento. Cuatro fanegas de trigo y media bota de vino, que se gastó en el hospital en los meses de noviembre y diciembre de 1633, dio Domingo González de Cecilia por la curación de su mujer.

NÚMERO DE HOSPITALIZADOS, PROPORCIÓN POR SEXOS Y TASAS DE MORTALIDAD

La media de ingresos desde que comienzan los registros de enfermos en 1674 hasta 1822, en los años anteriores al traslado de la institución al convento exclautrado de Santa Clara, fue de unos 59 pacientes aproximadamente ${ }^{43}$. Entre 1675-1680 fue de 48, cifra que se mantuvo a lo largo del siglo xviII para ir descendiendo hasta los 25 enfermos en los ańos previos (1780-1781) a la fundación de la Junta de Caridad

${ }^{42}$ La mujer de Domingo Camoneco (fallecido en la casa en 1794) pagó 18 reales «por la carne que se le dio». Dos años después, "dos portugueses que se estuvieron curando en el hospital muchos messes» abonaron 200 reales.

${ }^{43}$ AMSCP: Legajo 649, n. ${ }^{\circ}$ 1, libro 1. ${ }^{\circ}$ de enfermos (1674-1736); n. ${ }^{\circ} 2$, continuación del Libro $1 .^{\circ}$ de enfermos (1737-1774); legajo 650, $\mathrm{n} .^{\circ} 1$, libro 2. de enfermos (1774-1804); y n. ${ }^{\circ}$ 2, libro 3..$^{\circ}$ de enfermos (1804-1823). 
en 1782 ( $\tan$ sólo 19 en 1778 y 20 en 1780), años en los que además se admitieron en la casa, mantenidas a pan y carne, a varias niñas expósitas por no haber «quien las llevase» después de su año de crianza, por la mala nutrición que habían recibido o por hallarse enfermas sus amas de cría. Con posterioridad, su número comenzó a remontar hasta alcanzar más de 80 hospitalizados de media en las dos primeras décadas del siglo XIX (1800-1822), con picos de 119 pacientes en 1803, 109 en 1811 y 113 en 1816. Según el informe elevado en 1784 por los hermanos de la Junta de Caridad al gobernador eclesiástico, por lo común había de continuo en la casa entre ocho y diez enfermos, fuera de los muchos más «de los sumamente necesitados que claman por entrar en ella», cuya admisión la institución se veía obligada a negar para no desamparar enteramente a los nińos expósitos ${ }^{44}$. Por sexos, la proporción de mujeres fue siempre superior a la de los varones, diferencia que fue aumentando a lo largo del tiempo, al mismo tiempo que descendía la edad media de los ingresados. La mortalidad era muy alta a finales del siglo XviI, de modo que de 82 pobres que entraron para curarse en 1670-1671, tan sólo 32 recuperaron su salud. Entre 16741680 , fallecieron 110 de las 313 personas atendidas (35,14\%), tasa que, con altibajos, se mantuvo a lo largo de la primera mitad del siglo siguiente ( $40,54 \%$ en 1738 ; $25,64 \%$ en $1739 ; 36,36 \%$ en $1740 ; 38,18 \%$ en $1750 ; 30,95 \%$ en $1760 ; 34,21 \%$ en 1770), para comenzar a descender paulatinamente a partir de 1780 hasta situarse por debajo del $20 \%$ a principios del XIx ( $20 \%$ en $1780 ; 17,39 \%$ en $1781 ; 45,71 \%$ en $1790 ; 22,22 \%$ en $1795 ; 10,98 \%$ en $1800 ; 19 \%$ en $1805 ; 15,38 \%$ en $1810 ; 11 \%$ en $1811 ; 18,58 \%$ en $1816 ; 18,07 \%$ en $1818 ; 9,87 \%$ en $1821 ; 20,33 \%$ en 1822$)$.

\section{EXTRACCIÓN SOCIAL}

Casi sin excepción, la extracción social de los pacientes era muy humilde. Conocidos en muchos casos por sus motes populares, uso que aún se mantiene en la isla, la lista de apodos es interminable ${ }^{45}$. Pobres y mendigos de todos los luga-

${ }^{44}$ Para reducir el tiempo de hospitalización, en 1800 el establecimiento pagó cuatro reales por una bestia de carga para llevar a «una pobre convaleciente para su casa por el ahorro que resultaba al hospital de que se fuese».

${ }^{45}$ Pedro González Guinda la Vela (enfermo habitual, natural de Garafía, de 80 años de edad); Gabriel Hernández Porquería (natural de la otra banda); Baltasar Rodríguez Batato; Domingo Martín Malacosa; Pedro Hernández Gaveta; Francisco Hernández Polilla; Francisco Pérez Arrarrurra (de 50 años); Domingo Campana; Francisco Pechilango; Agustín Cachete; Cayetano el Vicho; José Alfiler; Ignacio Carnero; Carlos Caforiño; Diego Patacón; Francisco Escarabajo; Cristóbal Rapadura; Francisco Tufo; José el Cuervo; Matías Casquete; Andrés González Palometa; Baltasar Rodríguez Pulpo, etc. La lista de apodos femeninos es especialmente variada: María la Velosa (de 70 años); María Martela (de La Gomera, que murió con 22 ańos); Ana Chinana (de Los Llanos); María la Pájara; María Regañada; María Hernández la Pulga (de 23 años); María la Dorada (hija del hospital); María González Chicharra (de Tijarafe, de 63 años); Ana la Fula (esclava de don Marcos Urtusáustegui, de 70 años); Francisca Pérez la Nazarena (de 80 años); Ana Rodríguez Lagarita (de 69 años); María de Acosta la Morrińa (también de 69); María de los Ángeles la Sarga (moza de 45 años, vecina de San Telmo); 
res de la isla ${ }^{46}$, mozos solteros «sin oficio» por estar «ympedidos de la vista» o "por ser ymválidos», ciegos, cojos, paralíticos y tullidos de "mucha nesesidad» y edades avanzadas, enfermos habituales, insolventes y pobres de solemnidad con extrema necesidad, recogidos en la casa que cayeron enfermos, deficientes mentales, hijos de la cuna y de padres no conocidos, niños expósitos enfermos a los que nadie quiso proahijar después del año de cría, clérigos de menores, frailes y legos ${ }^{47}$, ermitaños y beatas ${ }^{48}$, pero especialmente viudas y viudos y solteros de ambos sexos sin familia próxima en los años finales de su vida (con 90 años entró María Antonia, natural de Los Llanos, y Marcos Rodríguez, "el páxaro», vecino de Breńa Baja, que murió a los 70 años en 1676); así como menestrales, jornaleros y artesanos de la ciudad, vecinos de los populosos barrios de Jorós, inmediato al hospital, el Puerto, San Telmo, San Sebastián, el tanque de Santa Catalina y La Somada y de las calles del Tanque y de los Molinos. En las cuevas de La Encarnación vivía María de la Encarnación. «Hinchada y tullida de necesidad estrema» y con más de 70 años, entró para morir un mes después. Esclavos, negros, mulatos, pardos, morenos y libertos ${ }^{49}$ de ambos sexos (de la isla o del resto del archipiélago) fueron numerosos y, como revela el libro primero de defunciones de la parroquia mayor de la isla (1637-1672), la iglesia del hospital fue el templo destinado por lo común al enterramiento de la población negra

María Pérez Infanta la Rajada; María Hernández la Paloma; Francisca la Graja; Nieves la Cantadora; Margarita la Porqueńa (pobre recogida); Gabriela la Chincha; Micaela Pelada; Manuela Xaramaga; Francisca Madruga; María Reverosa; Josefa Cavoca; Juana Rodríguez la Jara; Margarita Pelota; Josefa la Junca (ama de mandados); Rita la Matamoros; María Pilrrona, («pobre recogida en esta santa casa hospital»); Josefa García, «la Güeva»; Bernarda y Gerónima la Grilla; «Luisa frayla, hija de Argen frayle, soldado de España»; Xaviela la Breva; Josefa Gotera; María la Gaifola; Cristobalina la Tufa; Antonia Pichilanga; Josefa Moscona; Juana Coruja; Cristina Tareco; María Rola; Catarina la Arańa; Juana la Negra; Antonia la Pico; María Remedios Lindona; Isabel Pelón; Juana Carnera; Juana Cucaracha, etc. En ocasiones tan sólo el mote bastaba para su identificación: la Simonica, la Caboca o el marido de la Peladita. Bajo el sobrenombre de bobos - y la forma femenina- fueron internados varios deficientes, como Jacinto el Bobo (en 1760) y María y Francisca la Boba (que fallecieron en agosto y noviembre de 1790 en las semanas siguientes a su entrada). La procedencia de los hospitalizados también motivaba la adjudicación del correspondiente sobrenombre; sirvan los ejemplos de Feliza la Portuguesa (natural de Madeira), Tomasa Rodríguez la Gomera, Isabel «la de Tixarafe» y Julián «Lomo Obscuro».

${ }^{46}$ Con más de 60 ańos, Francisca González era una "pobre mendicante que andaua en la calle». Falleció en agosto de 1676, un mes después de haber entrado para curarse.

${ }^{47}$ A fray Blas de Armas, religioso lego del convento franciscano de Nuestra Señora de la Piedad de Los Sauces, enfermo "gálico» (sífilis), se le dio una unción en julio de 1803. Del mismo convento era el R.P. fray Sebastián Díaz, natural de la isla de Canaria, que, con 50 años de edad, ingresó el 15 de febrero de 1816 para ser tratado por unas «empolladas malinas».

48 Domingo García el Ermitaño, de 70 años, fue recibido en octubre de 1675; y Francisca de San «Elefonso», beata, de 50 años, en agosto de 1683.

49 Tras casi dos meses hospitalizado, Antonio Hernández, de color negro, liberto, falleció el 29 de abril de 1693. Nombró por albacea al mayordomo de la casa-hospital, a quien encargó destinar la mitad de sus bienes (una caja grande de madera del Brasil, tres fanegas de trigo que le debían en Puntallana y una lonja en la calle Real de la Somada) a su funeral y la otra a la «sustentación de los pobres de dicha casa». En los mismos meses de marzo y abril entraron dos enfermos tullidos de "color negro», María Ximénez, de 60 años, y Domingo de Abrantes, de más de setenta, que murió el 15 de enero de 1694. 
y esclava ${ }^{50}$. Hubo también moriscos ${ }^{51}$ e indios de las colonias americanas ${ }^{52}$. Ningún representante de la aristocracia o de los grupos sociales dominantes figura en los libros de enfermos. Llegado el caso, eran atendidos y convalecieron en sus propias residencias hasta su curación o fallecimiento. Como únicas excepciones, cabe citar a contados miembros de algunas familias de la burguesía local, como dońa Constanza Lindo, hermana de don Gregorio Lindo, guarda mayor de la Real Aduana, que entró para ser uncionada en 1760; y dońa Leonor Cullen y They, moza soltera de 59 años, atendida por dos veces, una por «siurgia» (1809) y otra por hidropesía (1811).

\section{Oficios}

Entre las actividades laborales más comunes de los hombres se incluyen jornaleros y peones, labradores y «servicio del campo»; pescadores y marineros de múltiple origen; oficiales y aprendices, zapateros, carpinteros, albañiles, pedreros, curtidores, herradores, toneleros, carreteros y arrieros de la ciudad y "de la otra banda", barqueros; y otros más esporádicos: hortelanos, viñateros, serradores (de Garafía), carpinteros de ribera, «mercadeles», cocineros, molineros, montañeros y pastores, «orchilleros», sepultureros, alguaciles, ministros de la Iglesia, pregoneros, así como otras profesiones más raras como un procurador de causas, un espadero y un sastre portugués enfermo del juicio que ingresó en 1775. Los sederos se hicieron numerosos en las décadas finales del siglo XVIII y principios del XIX. Mozos y asistentes de ambos sexos, cuya profesión era "servir a un amo" ${ }^{53}$, fueron particularmente abundantes, criados adscritos a las casas o a los miembros de las familias más pudientes y también a los conventos de frailes y monjas ${ }^{54}$. El personal sanitario (hospitaleras, amas de cría, sangradores) también era frecuentemente atendido o uncionado tras caer enfermo. Las ocupaciones femeninas se limitaban a amas, criadas, mozas sirvientes, aguadoras. En 1810 y 1811, las mozas solteras, con edades comprendidas entre $15-18$ y 84 ańos, representaban el 56,3\% de las mujeres hospitalizadas, seguidas por las casadas $(24,6 \%)$, con edades entre 24 y 69; y las viudas (19\%), de entre 31 y 64 años.

${ }^{50}$ Durante estas tres décadas fueron enterrados en la parroquia matriz de El Salvador 116 esclavos, en la del hospital 69 y tan sólo siete en los conventos de frailes y monjas de la ciudad. Véase APSSCP: Libro I de defunciones (1637-1642).

51 Valentín Méndez, morisco, fue enterrado en la iglesia del hospital en 1584.

52 En el tratamiento y purga de "Antón, yndio de Roberto Hernández», se gastaron cuatro onzas de unción y otra de hoja de sen en 1660.

53 Enfermo gálico, Matías Hernández (natural de La Galga y vecino de la ciudad, de 35 años) ingresó en mayo de 1808; su "oficio servir a un amo".

54 En 1657, se enterró a Pedro, "que servía a las monxas». Francisco Cordero, criado de los frailes franciscanos, natural de Barlovento, entró en la casa hospital, tullido y con más de 70 años, en septiembre de 1699. Moza de las hijas de don Pedro Pinto y criado de dońa Antonia de Sotomayor respectivamente, Clara y Mariano de la Concepción ingresaron en 1770 y 1781. 


\section{CUADRO CLÍNICO: ENFERMEDADES, AFECCIONES Y PADECIMIENTOS}

Tras la creación de la Junta de Caridad en 1782, comenzó a llevarse un registro (más completo a partir de 1802) de entrada y salida de enfermos, con indicación de edad, naturaleza y vecindad, estado civil, oficio, enfermedad y tiempo de estancia en la casa. Las enfermedades infecciosas eran las que afectaban a un mayor número de enfermos, en primer lugar la de "gaélico» o "gaélica», sinónimo de sífilis, tanto en hombres como en mujeres y niños. De los 200 pacientes atendidos en los ańos de 1810 y 1811, constituían el 40,5\% del total (81), un 40\% entre los hombres y un $37 \%$ entre las mujeres, cifra que aumentaba en algunos colectivos, como las mozas con edades comprendidas entre los 15 y 40 años (56\%). Los niños hospitalizados lo fueron en un alto porcentaje $(76,92 \%)$ por esta razón. El tratamiento más común era la unción sobre las llagas, que a veces recibían madre (mozas solteras en todos los casos) e hijo al mismo tiempo ${ }^{55}$. Por «bubas» (nombre por el que también se conocía esta enfermedad venérea), recibieron este método de sanación, en marzo de 1803, José María y María de los Dolores Rodríguez, Antonia Felipe Rodríguez, Francisca de la Cruz Rodríguez y Tomás González Ladillo, de 14, diez, nueve, tres y dos años respectivamente. El «erpie» (herpes) se cebaba en especial con las mujeres de todas las edades, mozas, viudas y casadas; mientras que las tercianas y las «fiebres ardientes» aquejaban a los soldados enrolados en los batallones y regimientos militares. Miembros dañados y «derriscamientos» figuran entre los traumatismos. El 18 de enero de 1693 entró Domingo Bernal, del barranco de Aguacencio, con un pie dañado «del qual se cortaron dos dedos y salió sano a fines de abril de dicho año». Desde el término de Los Sauces fue traído en unos varales Antonio Martín "por auerse derriscado», acompañado de su hija, en mayo de 1775. Entre los «baldados» se cuentan jornaleros, labradores, molineros, curtidores, peones, pedreros, carpinteros, marineros, pescadores y mujeres casadas.

La lista de enfermedades incluía toda clase de dolores, síntomas y afecciones: en primer lugar, la «siurgia», la «hinchazón» y la «hidropesía» (que acompañaba a muchas muertes, especialmente femeninas); «un edema», «un dolor», «dañado» o "dañada», «inflamación de garganta y dropesía», causa de la muerte de don Joaquín de Montesdeoca Hurtado, sangrador del hospital; "ampollas», "afecto cutáneo», «ysipela» o «edisipela» (erisipela), «tiricia» o «etirisia» (ictericia), sarampión ${ }^{56}$, "calenturas», "fiebres», "obstruciones» (obstaculizaciones del conducto del hígado), «golpe» $\mathrm{y}$ «dolor de costado» (apendicitis), desde los 19 hasta los 60 años; «enferme-

55 Es el caso de Juana Pérez, de un año de edad, que ingresó en el hospital para recibir una unción juntamente con su madre, Josefa Domínguez, en enero de 1803; y de Rita de Acosta, moza soltera de 26 años, y su hijo Esteban José, de siete meses, que entraron en mayo del mismo año. En septiembre de 1804 y en abril de 1805 lo hizo Josefa de los Santos, soltera de 25 ańos, primero con su hijo Pedro, de nueve meses, y luego con su otro hijo Diego, de cuatro años.

56 Por sarampión ingresaron el 25 y el 27 de marzo de 1809 un peón de 19 años y una moza de 21 -ambos vecinos de la ciudad- que salieron el 8 de abril siguiente. 
dad del pecho», «afecto de pecho», «accidente repentino», «opresión de pecho», «puntada», "puntada en el celebro», "ahogo», «sangre por la boca», "visantería» (disentería), casi siempre mortífera; «diarrea», "dolor de estómago», «mal de vientre», «dolor ventoso», «purgación», «empacho" ${ }^{57}$, «úlceras», «tumores», "heridas», «flatos», «flujo de sangre» $\mathrm{y}$ "mal de sangre» en mujeres casadas y viudas; "enfermedad de la vista», «resfriado», «enfermedad de la garganta», «hairadas», "ayre» en mozas, casadas y viudas; un herrero, un marinero y una casada con "asma»; "perlesía», en casos de jornaleros, labradores y hombres y mujeres de muchos años; «romatismo» $\mathrm{y}$ "dolores romáticos» en todas las edades; "dolor siático», «sabañones», «sarna», "enfermedad del juicio» y «locura» en jóvenes y ancianos ${ }^{58}$; tullidos y tullidas en avanzada edad al borde de la muerte ${ }^{59}$ y alcoholismo; sin que se excluyan, entre las enfermedades, la «necesidad» y «la extrema necesidad», la «vejez» (desde los 55 hasta los 90 años) en solteros y solteras, viudas y viudos; o ambas cosas a la vez; incluso se cita simple y llanamente el «hambre» ${ }^{60}$. También hubo casos de lepra, en una moza de 17 años y en una viuda de 48 ańos, naturales y vecinas de Mazo y Barlovento, respectivamente; de tisis o tuberculosis, en un labrador soltero de 30 ańos, vecino de Los Sauces, que ingresó en 1807; o de «excópulas», en una viuda de 31 años. La exposición a las enfermedades infecciosas fue causa de contagios tanto para el personal sanitario como para los familiares más próximos. María Carballa, vecina de la ciudad, se infectó en julio de 1677 "por haber venido a asistir a su marido».

La brutalidad de la época se refleja en los casos de apaleamientos y malos tratos. El 22 de diciembre de 1805 entró un mozo soltero de 22 años, natural del pago de Las Ledas, «apaliado», y otro de 36 años, natural de San Pedro, «herido de palos». Tan sólo 12 años de edad contaba Lorenzo José, natural del lugar de Buenavista, que estuvo convaleciente desde el 9 hasta el 11 de febrero de 1805 a causa de una paliza. A lo largo de 1805 y 1806 ingresaron cuatro pacientes por la misma razón: Miguel Marcial, natural de Mazo, casado, peón de 33 años, el 22 de enero de 1805; Domingo Hernández Baquero, natural y vecino de la ciudad, pedrero de 53 años, el 13 de enero de 1806; Pedro Martín, de Mazo, soltero de 30 años, jornalero, el 7 de febrero; y Andrés Cordobés, mozo jornalero de 43 años, también vecino de Mazo, que murió a consecuencia de las lesiones sufridas el 5 de octubre de 1805. Por su parte, Manuel Barrete, marinero soltero de 28 años, fue internado en septiembre de 1805 aquejado por una puñalada.

57 Margarita María Luis, moza soltera de 50 años, murió de empacho el 24 de enero de 1805, al día siguiente de su entrada.

${ }^{58}$ Con 89 años de edad falleció, el 1 de junio de 1806, Antonio Pérez, mozo y sirviente, natural de Los Sauces y vecino de la ciudad, que había ingresado por locura el 18 de mayo anterior. "Aguedita Hernández», moza de 25 ańos, natural y vecina del caserío de Las Nieves, entró el 27 de febrero de 1808 aquejada de la «enfermedad del juicio» y salió el 25 de abril siguiente.

59 En abril de 1694, entraron en la casa - por su «mucha necesidad»- Domingo Pérez, vecino de Velhoco, y Francisca Hernández, mujer de Sebastián Gómez, vecina de Buenavista. Tullidos -con más de 80 años de edad cada uno-, fallecieron poco tiempo después.

${ }^{60}$ Tomasa Sosa - moza de 24 años, natural de Garafía y vecina de la ciudad- entró enferma en la casa-hospital el 16 de abril de 1803; «su enfermedad», «hambre». Salió cinco días después. 


\section{DIETA Y ALIMENTACIÓN}

Según reglamentó la Junta de Caridad en 1782, a cada enfermo debía dársele «lo mejor, y solamente lo que sea necesario, pues es poco gouierno el señalarles ración de pan o de carne quando los vnos pueden necesitar más y los otros menos». Se preparaban dietas para los uncionados o para algunos enfermos con necesidades especiales o "con mucho fastidio", a quienes, por prescripción facultativa, se les daba, según los casos, chocolate, huevos mejidos, leche «de bestias» o de burras («un novenario» habitualmente), leche de almendras y leche de cabras ${ }^{61}$. Las dietas de los uncionados incluían gallinas (1746-1747), leche (1773-1781), pasas y huevos mejidos (1764-1765). Se hacían igualmente lavativas y enjundias con huevos y azúcar $\mathrm{y}$ «sustancias de pan y caldo para distintos enfermos». Calificada como «vn orror» por el mayordomo del hospital, estas preparaciones consumían muchas libras de pan traídas de casa de la panadera, como se denuncia en 1774 y en 1779. La grave falta de camas y el impedimento de algunos enfermos obligaban también a dar las raciones de pan y otros auxilios en las casas de los propios pacientes con el consejo del médico (1756-1757). La base de la alimentación ofrecida diariamente era una ración de carne (de seis onzas en 1814) y otra de pan, según se dice en 1784. Comprada en la carnicería, "según estilo» era costumbre pagar al marchante seis celemines de centeno como regalía o gratificación por el cuidado y puntualidad de la carne. Casi un $70 \%$ de la que se consumía era de carnero y, en su defecto, de vaca y de chivato ${ }^{62}$. Dentro de este capítulo figuran en la dieta de los pacientes la cabeza, carne y asadura de carnero, cabra, cabrón y «cabroncillo»; vaca y ternera; borrego, cordera y oveja, puerco o «serda», carne salada y excepcionalmente el conejo (17121713). A falta de carnero o por prescripción médica ${ }^{63}$, se servían huevos, gallinas y aves (pollos, capones, palomas, pichones) a purgados, paridas, niños hospitale-

${ }^{61}$ En 1800 se gastaron 14 reales y medio de plata en huevos para una enferma que no tomaba «otro alimento que huevos mejidos y leche».

62 Según reflejan los mayordomos de la casa en sus descargos, el gasto anual de carne a finales del siglo xvirI fue de acuerdo a la siguiente síntesis: en 1794, 1012 libras de carnero «en enfermos muchos y algunos nińos puestos en la cassa» (102 libras a 20 cuartos, «que fueron las vnicas que pude lograr que el marchante diera a dicho precio", y las restantes a real y medio de plata la libra); en 1795, 708 1/4 libras de carnero -a $1 \frac{1}{1} 2$ reales de plata-y 96 libras de vaca-comprada por disposición del médico, a real de plata la libra-; en 1796, 997 1/2 libras de carnero -a 1 1/2 reales de plata la libra- y 82 1/2 libras de vaca -a 12 cuartos-y 10 1/2 libras de chivato -a real de plata-, gastados «en los muchos enfermos que ha habido, entre los quales a los portugueses y soldados se les dava vnas vezes a media libra al día y a otras a tres quartas, en que se incluie también la dada a la ama Josefa y algún nińo de año puesto en la casa»; en 1797, 600 libras de carnero y 89 y media de vaca y chivo -542 a dos reales la libra y el resto a real y medio-; y en 1798, 1100 libras de carnero -a dos reales la libra-y 164 libras de vaca y chivo -a real y medio la libra-.

63 En diversas ocasiones, su consumo se justifica para «mesclar con la carne cuando no era suficiente» (en 1774-1779), por faltar la carne de carnero (en 1784, 1787-1788 y 1802), «por haber faltado el marchante con el carnero" (en 1786), por precisarse cuando entraba "algún enfermo en los días que no havía carne sino para los que estavan en la casa» (en 1799); o «en un día que faltó la carne» (en 1808). 
ros, amas de la casa de avanzada edad o enfermos «que la apetecían» ${ }^{64}$. Las gallinas (compradas, entregadas por los arrendatarios o recogidas de limosna) también se comían en algunos días especiales de la casa (Asunción, Concepción, Pascua o día de Reyes) o mezcladas con la carne cuando esta no era suficiente. Destinado a los sirvientes del establecimiento (amas, criadas, sacristanes), el pescado, fresco (sardinas, chicharros, caballas, cabrillas, viejas, abadejos, samas o pargos, picudas), salado o seco ("merluseto», bacalaos, arenques, pargos grandes) formaba parte del gasto ordinario en el siglo XVII, no así en el siguiente ${ }^{65}$. Los huevos, ofrecidos de regalo con frecuencia por campesinos y granjeros (al igual que los quesos), se gastaban en abundancia en lavativas, en los niños expósitos y en la cena de las noches, en las que sustituían a la carne. Se preparaban mejidos (batidos con azúcar y agua hirviendo). En 1764-1765 hubo escasez de huevos por el sarampión. Unos cuatro almudes de garbanzos se gastaban por lo común a lo largo del año, además de otras legumbres como arvejas, habas, chochos (1712-1713), lentejas y chícharos (blancos y negros) procedentes de las limosnas del campo y de los arrendatarios del hospital. Con garbanzos, chícharos, cebollas y azafrán se cocía el "puchero de los pobres enfermos» (1738). Ambas legumbres se cosechaban en las tierras que el hospital poseía en Tijarafe $^{66}$. Para completar su consumo se compraban algunas cantidades más (dos almudes), como los garbanzos de Lanzarote traídos en 1786, 1797 y 1805. El arroz aparece en la dieta en el siglo XviII, primero puntualmente (1706-1707) y después de manera más regular $(1758)^{67}$; mientras que los fideos se mencionan por vez primera en 1812. A principios del siglo XIX (1800-1815), se gastaban habitualmente unas dos libras de arroz todos los meses, compradas en la tienda del comerciante don José Gabriel Martín, vecino del barrio del hospital ${ }^{68}$. En los días de invierno durante el

${ }^{64}$ Las cuentas mencionan el gasto de «algunas aves para los enfermos» (en 1616); de una gallina para un purgado (en 1637-1638); para «la moza que parió en el hospital» (en 1644); las que se compraron para «un mulato portugués, marinero del navío de Jerónimo de Molina», que entró a curarse (en 1646) y "para dar sustento a Joseph Rosa que estaua mui necesitado» (en 1786); de una gallina "que apeteció un enfermo" y de otra para la "espitalera de la Montesdeoca» (en 1787); de la que se dio a "la Galana" (en 1789), a algunos enfermos y al ama Josefa (en 1795); de ocho gallinas para «los portugueses, soldados y otros nececitados» (en 1796).

${ }^{65}$ Los gastos anuales recogen un real de pescado y otro de sardinas para los sirvientes en $1637-$ 1638; un canasto de sardinas que dio de limosna el capitán Nicolás Massieu en 1648; o las cabrillas frescas que el sacristán llevó del muelle en 1647.

${ }^{66}$ Los tributarios de las tierras donadas en 1607 por Sebastián de Pais el Perulero en Tinisara (Tijarafe) pagaban una fanega de garbanzos en 1649, tres celemines en 1701 y dos a partir de 1744, embarcados por el puerto de Candelaria y puestos en la casa hospital a finales de agosto de cada año. Véase AMSCP: Legajo 629, n. ${ }^{\circ}$ 2, libro de fundo y relaciones (1800), ff. 45 r. y 46 r.

${ }^{67}$ En 1810 se gastaba «en días señalados por modo de principio a los enfermos y quando el médico lo receta».

${ }^{68}$ Desde que compró el solar en 1804, construyó su nueva residencia frente a la puerta de entrada al centro sanitario por el barranco; conservada en el día, se halla en el número 7 del orden actual de la calle Pérez de Brito y cuenta con fachadas orientadas hacia la avenida El Puente (antes, cauce del barranco de Los Dolores) y hacia la calle Pérez Volcán; véanse los detalles en Pérez GARCía, Jaime (1995): Casas y familias de una ciudad histórica, la calle Real de Santa Cruz de La Palma, 
almuerzo se servía a los pobres leche de almendras cuando faltaba la carne (1797). Las papas también se incorporan tardíamente (1795), cosechadas por el medianero de la hacienda de Buenavista ${ }^{69}$. A partir de entonces, se consumen con regularidad a razón de dos almudes mensuales (1802). Las verduras y hortalizas (cebollas, calabazas, ajos) se empleaban en el «puchero», buena parte de ellas, obtenidas de las limosnas del campo. Tres docenas de calabazas se gastaron en un año (en 1639) fuera de las que dieron de limosna. Las especias resultaban imprescindibles para condimentar la comida y el puchero: clavo, pimienta negra y sobre todo azafrán o «azafrán seco de España $»^{70}$, además de hierbas como el cilantro, el perejil, el «achote» (17111712), la matalahúga (anís) y la canela para la repostería, medicamentos y sudaderos. De olivo era el aceite del "gasto común», "para comer» o "para la cocina» de los enfermos, empleado también en las lámparas de la iglesia y de los salones; mientras que el de pescado, de ballena, de «loro» o de «laurel», o «aceite de luz», se utilizaba «para los candiles» o «para alumbrar» la casa. Según se explica en 1810, el azúcar se gastaba en pedacitos en los enfermos de unción, refrescos, limonadas y horchatas para los pacientes, en la preparación de algunos alimentos y en la composición de algunos medicamentos; y el vino cuando el médico lo recetaba, «a los enfermos, ancianos y débiles y aún a los expósitos de año», para diferentes remedios y para «los pobres mendigos en tiempos lluvia y frío» (1692-1694). Al igual que con el trigo, su consumo fue racionado en 1603 por el obispo Martínez Ceniceros entre los sirvientes del hospital para evitar gastos superfluos. Según su recomendación, resultaba más barato hacerlo en dinero, «quatro, seis u ocho maravedís o los que fueren nesesarios, que no darles vino», vendiendo «el que se allegare de limosna». Advertía de sus riesgos para la salud de los enfermos, «de donde se sigue que se les alarguen más sus enfermedades y al cabo no salgan curados». Por el contrario, tan sólo se les daría cada día «sigún lo quel médico mandare y no más».

Dulces, pasteles, bizcochos, bizcotelas, rosquetes y sobre todo «cajetas de membrilladas» (a base de membrillos y miel de abejas) $)^{71}$, «cajas de pera» (1764-1765) y cajas de conservas se elaboraban "para rregalo de los enfermos» (1615), con frecuencia a modo de limosna de los bienhechores. Como acto de caridad, los mayordomos del hospital tenían por costumbre repartir entre las personas piadosas cajas vacías para que las llenasen de conservas en sus casas ${ }^{72}$. Durante las fiestas señaladas del año se brindaban a los pacientes y pobres recogidos y a los trabajadores de la institución (amas, sacristanes, capellanes, médicos y cirujanos) platos especiales

Santa Cruz de La Palma, Cabildo Insular de La Palma-Colegio de Arquitectos de Canarias (Demarcación de La Palma), pp. 236-240.

${ }^{69}$ En ese año el medianero de dicha hacienda entregó $21 / 2$ fanegas de papas a 15 reales la fanega.

70 En 1635 Ángela Hernández entregó 50 reales al ama para gastos de la casa en «asafrán, pimienta y otras espeserias y ortalissas como consta de la quenta que la dicha dio».

${ }_{71}$ Desde 1627 aparecen con regularidad «cajetas de membrilladas» $\mathrm{y}$ «panes de mebrillada».

72 Dos docenas de cajas vacías se distribuyeron con ese objeto entre los bienhechores en 17561757. En 1788 el presbítero don Felipe Benicio de León, mayordomo del hospital, compró otras 24 cajas de conserva repartidas «con algunos fieles quienes las llenaron de dulse para el gasto de los pobres enfermos». 
en el almuerzo, especialmente dulces: «cubiletes» de carne preparados con manteca de puerco y especies, asaduras, gallinas y frascos de vino (1785), "templas de bizcotelas» (1764-1765), rosquetes, bizcochos y pasteles, con los que también se obsequiaba a los predicadores invitados o a los estudiantes que representaban las comedias (1648). Así se hacía en Navidad, Año Nuevo y Reyes, Jueves Santo y día de Pascua, así como en las dos fiestas que celebraba la casa: la Asunción y la Concepción de Nuestra Señora. Algunos de los dulces más tradicionales de la repostería de la isla aparecen desde antigua fecha, como sucede con las populares «rapaduras» palmeras (1712-1713) y almendrados, documentados desde 1654, hechos con azúcar, huevos, limón y almendras ${ }^{73}$; o las «roscas» de pan de manteca que aún se hornean por el mes de diciembre en La Sabina y en Hoyo de Mazo, ofrecidas a las amas y mozas por Pascua de Navidad ${ }^{74}$. En el postre de los enfermos también figuran frutos secos, pasados y de temporada: «almendras de la otra banda ${ }^{75}$, pasas, ciruelas, brevas e higos pasados, castańas y plátanos (1647). A los niños expósitos se les nutría, mientras estaban en la casa, con miel de abeja y jaleas, aceite dulce, miel mezclada con aceite y con harina, papisas, zahínas, poleadas y gofio (18141815), vino para sopas (1646) y aceite para migas. Un almud de almendras y una libra de azúcar blanco se dieron en 1666-1667 a María Normán "para almendradas del niño Juan, que se murió luego». A principios del siglo XIx (1802-1810), el hospital compró algunas cabras que varios mozos y criadores de las proximidades de la población (del barranco de los Dolores, Velhoco y Mirca) se ocupaban de cuidar, dar de comer y conducirlas al hospital para amamantar con su leche a los niños por la mañana y por la tarde, trabajo por el que recibían 20 cuartos por cada día o un real cada semana ${ }^{76}$. Los infantes en estado de mucha delicadeza, de más de un año, eran alimentados con leche, bizcochos, azúcar blanco y mascabado y caldo, además de muchos huevos mejidos ${ }^{77}$.

${ }^{73}$ El 14 de septiembre de 1654 se gastaron dos reales y medio en azúcar y almendras «para vnas almendradas para vnos enfermos».

${ }^{74}$ Se citan en 1808 y en 1812-1813. En las cuentas de estos últimos años figuran un almud de trigo y manteca de Flandes para cuatro roscas «que se dan a las amas por las pasquas de Navidad».

${ }^{75}$ En 1673-1674 se recibió un almud de almendras, «manda de un hombre de la otra uanda».

${ }^{76}$ Once pesos y seis reales de plata importó comprar y mantener una cabra para dar leche a los expósitos por espacio de cinco meses, con la soga para amarrarla y un real cada semana al que la traía al hospital mańana y tarde (agosto de 1810). Otros cinco meses la tuvo Manuel García, de Mirca. Un año después, otra cabra permaneció en la ciudad durante tres meses dando leche a los expósitos, además de un mes y días que estuvo en mantenimiento en Mazo, «donde murió de la enfermedad que llaman aquí tetera».

77 Con azúcar blanco y mascabado se alimentó «por más de dos meses vna niña que entró en la casa ya criada enfermita que se mantenía solamente con gueuos mejidos y caldo en refrescoz» (17731774). Según se dice en 1774, en el mantenimiento de los niños expósitos se gastaban muchos huevos. 


\section{TRATAMIENTOS CURATIVOS Y MEDICAMENTOS}

Los gastos de botica y boticario suponían un elevado desembolso para la casa-hospital. 836 reales y medio se pagaron a Juan Bautista Izquierdo por «purgas, letuarios, jaraues e ynguentos, unceón y otras drogas que dio para curar los emfermos» durante 1628-1629. La botica del padre franciscano fray Diego Casanova proporcionó los medicamentos recetados por el médico del establecimiento. Hijo de «la Casanova» (Isabel de Casanova), en cuya tienda se compraba azogue, aceites y plantas medicinales para la casa, elaboró purgas y onzas de unción para diferentes pacientes desde al menos 1654 hasta su muerte en 1678. Otra farmacéutica, Ana «la boticaria» (Ana Francisca), vendió diferentes remedios para la curación de los enfermos desde 1697 hasta 1710. Se conservan las relaciones de los medicamentos hechos por el médico Tomás Colón en 1765, con purgas, vomitorios, ungüento aperitivo, papeles de polvos, purgas de píldoras, polvos absorbentes, píldoras antihistéricas, cocimiento catártico, ungüento nervino, media onza de diapalma, polvos mercuriales; por el doctor don Domingo Ximénez en 1788, con ungüentos, purgas, vomitivos, polvos y bebidas; y por Jacinto Cullen en 1789, con purgas, papeles de polvos, dosis de purgantes, un "emplasto matrical» y otro antihistérico, un ungüento precipitado, zarzaparrilla, una bebida, onzas de maná y agua de canela. Para pesar los medicamentos enviados de la botica, el mayordomo Francisco Salcedo, presbítero, compró unas balancitas en 1795. De Cádiz procedían los que en 1812 se compraron en 26 pesos a don Luis van de Walle, que, por necesitarlos una enferma (María de la Concepción Cachita), «los soltó en dicho precio». A falta de boticario en la ciudad, los remedios se preparaban en la casa-hospital. Para ello se compraban, por orden del médico, en las tiendas y en las casas particulares ${ }^{78}$ diferentes plantas medicinales, elementos químicos potencialmente tóxicos para la salud como el azogue o mercurio y el albayalde y diversos productos farmacológicos: zarzaparrilla, almácigo, alhucema, hoja de sen y cańa fístula, ambas laxantes naturales; alcanfor y solimán (plantas que se usaban con fines medicinales) para lavar heridas y pinchazos, trementina o «termentina» (oleorresina semifluida que también se usaba para curar llagas), raíces, rama, hierbabuena, «manzanilla y otras hierbas medicinales» (1810), onzas de maná (1746-1747), lamedor de Agraz (1809), zumo que se extraía de la uva aún sin madurar; "palo encarnado", "palo dulce» y "palo morado", aceite de loro, de bayas y de "vagas para unturas», aceite de linaza para ungir, higos blancos, canela (para sudores), azafrán (para emplastos y madurativos), vino y aguardiente para lavar llagas y heridas, vinagre para gárgaras y vegigatorios (1797), piedra alumbre (para heridas), jabón y jabón de castilla (para madurativos y medicamentos), velas de Flandes para remedios, miel de abeja, azúcar blanca y mascabada (empleada en la composición de algunos medicamentos), baña o manteca de puerco... Tanto el aceite de oliva como la baña de cerdo y la manteca de vaca (al igual que el azúcar) se prepa-

78 En casa de Águeda Jorxe se compró una onza de hoja de sen y en la de «la Casanova» el azogue (80 reales) consumido en la casa-hospital en 1637-1638. 
raban con pétalos de rosas maceradas y esencias para hacerlos «rosados» y "violados» (1756-1757), dados sus efectos curativos sobre la piel. Con manteca de puerco se componía «el mercurio quando no lo había en el botiquín de la casa» (1810). En las lavativas de los enfermos se gastaban muchos huevos, además de azúcar blanco y mascabado. Igualmente se preparaban aguas e infusiones (para las que se hizo una cafetera en 1811), agua de «borraja y almirones» (1769-1771), "agua de cebada para tomar algunos enfermos» (1798). Los frascos de «agua de la reina» (1789) eran tónicos y extractos aromáticos de romero y aguardiente. Para preparar las unciones y baños se empleaba azogue o mercurio (1602), aceite y azúcar, unto y baña de puerco, albayalde y trementina (1639); y para las poleadas de los uncionados harina y miel de abeja. Una libra de «theziaca fina de Benecia y media libra de lebentina para la cura y unçiones de los enfermos» vendió en 1646 un cirujano alemán "que bino en un navío ynglés a este puerto». En la primavera de 1647, el boticario Andrés González Ximénez preparó una olla de unción con azogue, albayalde, incienso y jengibre para curar a los enfermos de bubas. Dos años después realizó otra unción con almendras, dos onzas de hoja de sen, dos libras de «baña pes griega», cera de ungüentos, aceite de pescado, ocho reales de bacalao, ocho reales de "adriaca termentina", albayalde, media libra de azogue, piedra lumbre, incienso y otros aceites e ingredientes. Con aceite de linaza y albayalde se untó a dos pobres que tenían las manos quemadas después del incendio que asoló la manzana situada frente a la iglesia del hospital en 1798. El vino, el aguardiente y el vinagre se utilizaban para los sudaderos y con él se daban bańos y se lavaba a los enfermos y uncionados. El primero se tomaba en infusiones con retama (1812-1813) o en cocimientos $^{79}$. Para curar a los pobres se usaba el vino blanco (1786). Ungüentos, pomadas y bálsamos se aplicaban sobre llagas y heridas o para sanar y aliviar las infecciones de niños expósitos o deficientes mentales ${ }^{80}$. En la elaboración de los ungüentos se empleaban diferentes sustancias grasas: cera blanca (1637-1638) o amarilla (1786), resina (1805), cebo (1809), aceite y aguardiente (1785), jabón y albayalde (1787-1788). Ungüentos de palma, de albayalde y «sanalotodo» constan en las cuentas de 1787-1788. Las "pócimas y jarabes» (1599-1639) se hacían con hoja de sen, azúcar, zarzaparrilla, hierbas y raíces. La miel de caña, la de abeja y «la miel gruesa» se usaban "para ayudas y otros medicamentos» (1692-1694) o para las llagas (la de abeja) de los enfermos de «ciurxia» (1788); el vinagre y manteca de puerco para cataplasmas (1802), el aguafuerte, la pólvora y el vinagre como desinfectantes ${ }^{81}$. Según consta en 1810 , el jabón lo recetaba el médico para baños (1810), mientras que el aguardiente se gastaba sólo en baños con pólvora y alcanfor. Con un emplasto para el ombligo, sanó Josefa Manuela, una niña de dos años de edad «que dicen que está por él quebrada» (1756-1757). El lino servía para atar los pulsos (1798), para «cortar la mano a un

79 La mayor parte del vino tomado por los enfermos en 1812-1813 fue en infusión con retama. En 1797-1798 se pagó un real y 12 maravedís «a quien traxo dos fexes de retama para componer un vino con la senisa».

${ }^{80}$ En 1789 se gastó un real de plata en el ungüento que se dio a «Chepa la boba».

${ }^{81}$ En 1808 se empleó pólvora y vinagre en la muerte de una hética. 
pobre» (1704-1705), para las heridas (1706-1707) o administrar la sagrada unción a los enfermos (1773-1774). Dos libras de estopa se emplearon en 1709-1710 para curar a los "yngleses enfermos" y media vara de bayeta y un real de papel vaso para «enbilmar la pierna de un herido» en 1797. Vendas y vejigatorios se confeccionaban con coleta $^{82}$, lienzo casero (1800), lienzo portugués y especialmente con crea (1796). En junio de 1811 se compraron a don Félix Baptista 50 varas de este tipo de tela cruda de algodón para hacer vendajes «a pedimiento y con dirección de los facultativos». En la operación que se practicó ese mismo mes a un «hombre derriscado en la fábrica» de la casa del mencionado Félix Baptista, se gastaron 10 reales de plata en hilo para coserlos, además de un frasco de vino y cuatro reales de bizcochos para los facultativos, sangradores y otros operarios que asistieron y velaron. Con lienzo portugués se hacían de igual forma las toallas con las que se limpiaban los cirujanos (1796). Las mantas y sábanas gastadas por el uso se aprovechaban para aplicar las unciones y purgas; y las sábanas y camisas viejas para amortajar a los difuntos, cosidas en la casa con hilo. El presbítero don Antonio Salazar y Carmona dejó, a su salida como mayordomo en 1774, un baúl lleno de ropa para mortajas, solicitada a algunos particulares y al veedor de la isla de Tenerife, al que pidió por carta que le enviase distintas mantas y sábanas de los expolios de los soldados difuntos.

\section{HIGIENE: ALBEO, PINTURA Y LIMPIEZA}

Como medidas higiénicas, las salas de enfermos, cuartos de héticos, de unciones y de la cuna, patio y corredores, portería, comedor y habitaciones del personal del establecimiento se encalaban y albeaban habitualmente y se evitaba que el aire infecto de las enfermerías pasase a otras estancias. En 1773-1774 se encaló el corredor «assí por arriua como por deuajo» y se albeó y fregó toda la casa. A juzgar por la documentación, estas medidas higiénicas se incrementaron además en la segunda mitad del siglo XVIII con fregados de salas y enfermerías e incineración de la ropa, sábanas, colchones y camas de los enfermos contagiosos y de la ropa de las unciones. Esta operación tenía como escenario la playa, con madera de tea proporcionada o comprada para este fin. De ello se encargaba el sepulturero, retribuido en diferentes ocasiones por quemar las camas y colchones de los enfermos muertos «por enfermedad pestilente» (1756-1757, 1764-1765, 1785), la «ropa de los héticos» (1756-1758, 1771-1773), la «ropa inficionada» (1785) o la "ropa de la cama de Pillita» (1786) ${ }^{83}$. Los colchones de los pacientes se lavaban y se secaban además al sol, para cuyo objeto se colocaron cuatro estacas y dos «latas» ${ }^{84}$ en 1703-1704. De los fregados se encargaban una o varias mujeres, a quienes se les pagaba una módica

${ }^{82}$ En 1743-1744 se hicieron unas vendas «para ligar a vm pobre que se hinchó» con dos varas de coleta.

${ }^{83}$ En 1785 se le dieron ocho reales 15 maravedís al sepulturero, «1 real de plata por enterrar a una pobre y el resto por quemar su ropa, la ropa de unciones y comprar tea para dicho fin».

84 Sinónimo de varas. 
cantidad. 12 cuartos se abonaron en 1746-1747 a una mujer por fregar la sala alta; 32 maravedís a otra que fregó en 1785 la parte de la sala donde estaba Pedro de la Concepción; dos reales y 24 maravedís a quien fregó en 1798 la sala del ama de cría «por haber entrado otra de nuevo por estar ynficionada de lepra la que salió, incluso en este fregado la cuna y un taburete en el mar"; y tres libras de pan a las mujeres que fregaron la casa en los años de 1811 y 1812. Con alhucema (planta similar a la lavanda) se "alhucemaba" la ropa y se ambientaban y perfumaban las salas y enfermerías, especialmente en los casos de enfermedades pestilentes ${ }^{85}$. El gasto de la casa incluía el «jabón de castilla» y el «jabón de cebo», este último sólo cuando había colchas que lavar (1811). Para hacer la colada se usaba igualmente la ceniza (1697-1698).

Desde 1797, también constan noticias de los colores y las pinturas aplicadas con el mismo fin sobre paredes, puertas, catres y cajas de orinales, y del almagre, añil, engrudo y aceite de linaza empleados en elaborarlas ${ }^{86}$. Las cristaleras no se documentan hasta 1764, cuando se colocaron los vidrios en las ventanas del cuarto de unciones, del coro, de las dos que miraban al patio en la sala alta de enfermos, de la del "cuarto de oir misa los convalecientes en la sala baja de enfermos» y de la de la sacristía (en estos últimos casos, ofrecidos de limosna). A partir de entonces se menciona regularmente la colocación de vidrios: en las ventanas de la enfermería en 1788 , en las de las salas en 1795 y en «las vidrieras» en 1797; y la compra de «vidrios de vidriera» (una docena en 1784), de vidrios, a moneda, para las vidrieras, "tiz y aceite de linaza» para ponerlos (1800) y «vidrios y medios christales, a 2 reales plata cada uno, para las vidrieras de los salones por no encontrarse de los comunes» (1805).

\section{ADMINISTRACIÓN DE LA CASA Y PERSONAL HOSPITALARIO: MÉDICOS, SANITARIOS Y SERVICIALES}

La administración del establecimiento corría por mano del mayordomo (en sus primeros tiempos conjuntamente con el hermano mayor o el prioste del hospital), encargado de abonar los «salarios de la casa», pagar el trabajo o simplemente dar comida y vestuario a médicos, cirujanos y sangradores, amas enfermeras, cocineras y

${ }^{85}$ En 1773-1774 se gastaron 16 reales y dos cuartos en alhusema, especialmente en la «sala de éticos», que estuvo «doz meses sin apartarse de ella por lo pestilente de la enfermedad de vn pobre que fue Gregorio el de Garafía».

${ }^{86}$ En 1797 se pagaron 24 pesos a Tomás Ramos por el «ynporte de los colores y mi trabajo personal de las pinturas hechas en la casa ospital»; en 1800, ocho reales «de colores para pintura», dos de garras para engrudo y ocho reales al que pintó los salones; en 1802, ocho reales de plata por cinco onzas y media de añil compradas en la tienda de don José Gabriel Martín para la pintura del salón de mujeres; en 1805, diez reales de seis almudes de color almagre para los salones; en 1808, dos pesos por pintar las dos salas altas y albear las bajas con una fanega de cal conducida desde el horno a la casa; en 1810, 20 reales por pintar las cunas de expósitos con una libra de pintura azul y un cuartillo de aceite de linaza; y en 1811, 84 reales por pintar los «catres, caxas de orinales y salones», con inclusión de pinturas, aceite de linaza, engrudo y pintor. 
de calle, amas de leche, mozas, criadas y esclavas, mamposteros o limosneros de hospitales, sepultureros y mandaderos, sacristanes, capellanes, sochantres y organistas.

\section{MAYORDOMOS}

Según reglamentó la Junta de Caridad en 1782 en sus constituciones, el mayordomo debía ser «el sujeto que a toda ora tenga la inmediata inspección y gouierno en la distribución y manejo de las rentas y en su economía, como también en el cuidado de los pobres enfermos». Desde la fundación de la institución, fue desempeñado sin tomar sueldo alguno, únicamente por caridad con los pobres. Así lo mantuvo la nueva junta, con la salvedad de que, en caso necesario, no fuese hermano de la misma o dejase de serlo en adelante, «porque ha de ser máxima constante de esta junta que ningún hermano se mueba por otro interés que el de Dios, sin mescla de los del mundo». Para tal oficio, se debía elegir siempre a un hermano con el «mayor zelo e inteligencia, pues de él depende en gran parte el arreglo y bentajas del hospital». A su cargo se hallaba el cobro de las rentas del hospital, «assí las del dinero, como de trigo, hazer las prouiciones para alimento y ropas y assí mismo el cuidado de la yglesia en las cobranzas, entradas y gastos y hazer las funciones y demás que corresponda a la capilla como capellán de ella». Como un «discreto despensero que solo dará lo que se nesesite», debía proveer de víveres a la casa y, en la última junta de cada mes, daría cuenta por escrito de lo gastado y cobrado, con distinción de cosas y de ramos. Integrada por 24 hermanos, doce sacerdotes y otros doce seglares, la Junta de Caridad estaba presidida por un hermano mayor y un presidente, cargo que recaería siempre en el vicario eclesiástico de la isla. Además de un mayordomo y un contador para llevar la administración, entre los hermanos se nombraba, por elección, a cuatro consiliarios o consejeros, dos eclesiásticos y dos seglares; además de un mayordomo, un secretario, un tesorero y un contador. Este último tomaría las cuentas anuales y llevaría registro de las limosnas recogidas cada semana, que, en caso de necesidad, entregaría al mayordomo para alimento de los pobres. En la junta de cada sábado se designaba a dos hermanos, uno de cada estado, para hacer los ejercicios de la semana siguiente. Juntos visitarían los pobres

por la mańana y la tarde, y se informarán si se les ha dado de comer y qué ha sido la comida, si el médico y el cirurjano les ha uicitado (a lo que se les obligará dos vezes en el día) y si se les han administrado las medicinas recetadas. Reconoserán si las camas, las salas, la cosina y demás cosas pertenesientes a los pobres están con el aseo y limpiesa deuida y mandarán aquello que no esté con todo arreglo y sea nesesario para dar aliuio a los pobres, participándolo a la junta en el sábado inmediato, para que determine lo conveniente sobre ello.

Otros dos hermanos, sacerdote y seglar, pedirían todos los miércoles limosna por las calles y otros dos se ocuparían de ir «a uer los pobres que pidan venir al hospital y reconocerán si son verdaderos pobres y si están enfermos y cuidarán de traerlos y acompañarlos al hospital, disponiéndose por la junta una silla para aquellos que no puedan conducirse de otra manera». En los lugares del campo se nombra- 
ban hermanos supernumerarios para recoger y remitir las limosnas "para ayuda de esta santa institución por desfrutar todos de este beneficio».

\section{MÉDICOS, CIRUJANOS Y BOTICARIOS}

Para la curación de los enfermos existía una plaza de médico y otra de cirujano, cuyos salarios se ajustaban según las medicinas, purgas y unciones que se obligaban o no a dar. El licenciado Juan de Cervantes ${ }^{87}$ lo hizo en 20000 maravedís anuales, precio en el que se concertó en el cabildo de vecinos celebrado en julio de 1600 en la casa-hospital. Por 20 ducados se comprometió en 1616 el cirujano Juan Díaz de Portalegre a "curar y poner los yngüentes de su casa». Con la misma cantidad fue retribuido en 1633-1634 el licenciado Manuel Ravelo, médico, aparte de otros 240 reales que cobró por 30 purgas que dio a los enfermos, «porque los demás medicamentos de xaraues y unçiones se hicieron en otra parte». A cirujanos y barberos se les pagaba en dinero por hacer "todas las sangrías neçessarias» (1618) o en trigo (cuatro fanegas al año) por «asistir a sangrar y curar las llagas a los enfermos» (1634-1636). Un boticario, ajeno a la casa, se encargaba, por lo común, de facilitar medicamentos, pócimas y ungüentos. Por real cédula de Felipe IV firmada en Madrid en 1664, el rey autorizó al cabildo de la isla a contribuir con 50000 maravedís de sus propios y rentas para ayuda de conservar y dar salario competente al preceptor de gramática y al médico, cirujano y boticario, ratificando la licencia anterior de 1654. A lo largo de los siglos XVII y XVIII figuran médicos, cirujanos y boticarios andaluces, flamencos, portugueses, franceses, ingleses e irlandeses que trabajaron por cortos periodos de tiempo (el maestre Juan, flamenco, que sirvió desde abril a agosto de 1617 y dio purgas y jarabes; el inglés Thomas de la Haya, que hizo curas y medicamentos a varios pacientes en 1664; y el portugués don Tomás de Ocaña en 1769, todos ellos cirujanos) o se avecindaron en la ciudad, contrayendo matrimonio, como los andaluces Cristóbal Rodríguez, barbero, cirujano y soldado (1622-1633); Juan Bautista Izquierdo (1620-1629), natural de Jerez, médico y boticario, yerno del cirujano Bartolomé de Funes; el doctor don Jacinto Doménech (1635-1638), médico, natural de Tortosa; el doctor Daniel Merario (1652-1654), originario de Avińón; el doctor don Francisco They, natural de Londres (1703-1738); y los médicos y boticarios de origen irlandés Tomás Colon y Jacinto Cullen. El pintor y escultor palmero Marcelo Rodríguez de Carmona entró a servir de cirujano en 1788. De carácter díscolo y altanero, fue suspendido de su salario un año después. De hacer y dar unciones se encargaban igualmente frailes y «mujeres curanderas» (1779-1780). A mediados del siglo XVII se menciona sucesivamente a «la mujer que dio las unciones» (1634-1636), a Francisca Luis Guzmán por dar las unciones en el discurso del año (1636-1638); a «Ynés Gomes la gusmana por las manos de vnciones que dieron

\footnotetext{
${ }^{87}$ Contrajo matrimonio en la iglesia mayor el 3 de julio de 1596 con Juana Pérez, hija de Ana Pérez.
} 
a los enfermos de bubas por la primabera passada» (1646); y a «la Gusmana por dar las unsiones demás de lo que se le dio en los meses» (1649).

\section{AMAS DE ENFERMOS Y AMAS DE SERVICIO}

Aparte de atender a los enfermos, el trabajo del ama u hospitalera era, al mismo tiempo, de ama de llaves y enfermera, de modo que incluía la cocina, amasar y hornear el pan, limpieza de camas y aposentos y lavado de la ropa. En esta labor era ayudada por mozas y criadas y, eventualmente, por esclavas ${ }^{88}$. Para el sustento y gasto diario de la casa se le entregaban el trigo y el centeno, el vino, la miel, las especias y hortalizas, el jabón, etc., o el dinero para comprarlos; además de llevar la cuenta del grano que proporcionaba para sembrar en las tierras del hospital (16021603) o de las sacas y cargas de carbón y leña gastados en el establecimiento «según memoria del ama» (1634-1636). Con el paso del tiempo, en el siglo xviII, se distingue entre «ama primera» $\mathrm{y}$ «segunda» o «ama de la casa» $\mathrm{y}$ «sirviente» (1738-1745), «amas de servicio de enfermos» $\mathrm{y}$ «de calle» (1788-1789), «ama de pobres» $\mathrm{O}$ «ama de enfermos» $y$ «ama de calle» (1797). A principios del siglo XIX (1800-1815), su número aumentó a tres: ama de llaves, ama de cocina y moza de calle o mandadera. El salario del ama de casa y del ama sirviente era a mediados del siglo XVIII (1738-1745) de 50 reales anuales y tres reales semanales para su conducto o sustento, aparte del trigo "para el pan de las amas» (seis fanegas al año, a razón de media fanega cada mes) o la ración entera de él que se les servía diariamente ${ }^{89}$. Debido a la dureza y a los riegos de su trabajo, podían ser relevadas al poco tiempo por otras amas, caso de María Simón, que, tras su sustitución, permaneció convaleciente en el establecimiento durante algunos meses. Águeda Bernardina, ama segunda, murió en abril de 1739 después de haber sido hospitalizada desde septiembre del año anterior; mientras que Josefa "Furundela» reemplazó en 1775 a Josefa de los Reyes, ama de enfermos, que soltó la casa por la misma razón. Una ama de enfermos y tres «amas de mandados» cayeron enfermas en 1780, 1782 y 1783. Llegada la vejez, el hospital corría con el sustento de las que permanecían en él. Retirada y mantenida por la institución a causa de su avanzada edad, al «ama Josefa» se le dio la pitanza de pan

${ }^{88}$ Natural de la villa de Zafra, Inés Gutiérrez, ama del hospital, dejó por heredera a la casahospital en el testamento que formalizó el 12 de noviembre de 1586 ante Diego de Luján. En sus mandas dejó a Catalina, «esclava de la dicha casa, todas las camissas y rropa hordinaria que tenía»; y a Mencía, "que sirve en el dicho hospital, doncella pobre», un colchón, una sábana, una fresada, una almohada y un faldellín pardo, todo de su uso. Declaró que Violanja Gómez, mulata retraída en él, le debía 10 reales de un manto; y Luis Buenaventura, capellán de la misma institución, cuatro o seis doblas por el alquiler de la casa donde vivía. "No murió de la enfermedad» y otorgó un segundo testamento el 16 de septiembre de 1594, «ama de la cassa y hospital de Nuestra Señora de los Dolores de esta ysla de La Palma y moradora en ella, estando enferma del cuerpo, sana de la boluntad». APSSCP: Libro del cumplimiento de los testamentos, ff. 118 v.-119 r.

${ }^{89}$ En 1799 el ama de pobres recibía tres reales cada sábado para su conducto y 45 reales anuales por su salario. Por su parte, el del ama de calle cobraba dos reales y medio cada sábado y 37 reales al año. 
y carne «hasta que murió» (1798), en lugar de trigo y de real y medio cada semana. El centro sanitario se encargaba de su vestuario y numerosas referencias recogen las tocas, mantellinas, jubones, justillos, camisas o cuerpos de camisas, sayas, faldas, enaguas, delantales y mantos comprados para uso de amas, criadas y servicialas. Por Navidad o las fiestas de la Concepción y la Asunción, «según costumbre» (1784), se les daba un par de zapatos, al igual que al sacristán y al mozo de calle. En algunos casos, ropa y comida fueron su única retribución. A las tres mujeres «que asistieron al servicio de los enfermos y niños» se les pagó, en 1633-1634, "con la ropa de dos muxeres que murieron en la casa, que fue la de Bosso Blanco y otra muxer de los Galguitos y algunas cossas que de la dicha caza y limosnas que se aprovecharon y no se les dio otra cosa». Un año después se dieron 10 reales al "ama para una saya porque no gana salario».

\section{AMAS DE LECHE}

Aparte de las amas de casa o de llave, en la casa-hospital existían una o varias «amas de leche», «de pecho», «de cría», «de cuna» o «nodrizas» con el fin de amamantar a los niños expósitos que caían en el torno ínterin permanecían en el establecimiento ${ }^{90}$, algunas de ellas recluidas dentro de sus muros en régimen de prisión. Este servicio o plaza fue dotada en 1657 como obra pía por el capitán Luis Maldonado, quien en sus últimas voluntades testamentarias dejó 200 ducados "para que en dicha casa se conseruase vna ama de leche para que los niños que se expusiesen a las puertas de dicha casa le diese leche mientras no hubiese quien los criase, a la que no pueden obligar los maiordomos críe más de aquellos que buenamente pueda ${ }^{91}$. Su salario era algo más elevado que el de las otras amas ${ }^{92}$ y, como a ellas, se les daba una bula para que pudiesen comer carne los viernes, vigilias y cuaresmas, de manera que su leche no menguara por esta causa. Cuando se reunían demasiados niños en la cuna de expósitos, se contrataba temporalmente a una segunda ama de leche durante los meses que fuese necesario. Cinco reales 30 maravedís hizo de costo en 1796 «el conducto de otra ama de cría que fue precisso entrar para aiudar a la otra a criar los muchos nińos que caieron en 3 sábados».

90 En 1764-1765, María de la Encarnación y Josefa Pérez Pechilango -viuda de Pedro Martín Tripa-recibieron 60 reales por «su salario anual de media leche que paga la cassa para los niños que caen en el torno mientras los lleban a criar».

${ }^{91}$ AMSCP: Legajo 629, n. ${ }^{\circ}$ 2, libro de fundo y relaciones (1800), f. 179 r.

92 En 1799 se pagaron al ama de cría tres reales cada sábado para su conducto, 60 reales por su asistencia en la cuna y 120 por criar a un niño. Otra ama de cría estuvo mes y medio ayudando a criar a otros cinco nińos a 12 reales al mes. 
Cuatro o cinco mujeres, doncellas por lo común, integraban habitualmente el número de amas, mozas y criadas. Entre 1669 y 1675 sirvieron en la casa varias de ellas, conocidas por sus nombres o sus apodos ${ }^{93}$. Durante más de 36 años lo hizo Francisca, causa por la que asistieron a su entierro, en 1671, los tres beneficiados de la iglesia mayor. Por entonces, falleció Margarita la "Capota», criada durante más de 14 años. Con más de 60 años murió en 1692 otra criada, Águeda Camacha, que «falleció derriscada de la escalera que sube a la sala»; y con 68 Isabel Blanco, criada de color pardo, que murió en noviembre de 1696, tres meses después de haber enfermado. A razón de ocho reales al mes, se pagó a Luisa de Riverol, de Barlovento, y a María «Mona», de La Breña, en 1703-1704.

\section{LAVANDERAS}

De la colada de la ropa de los enfermos se ocupaba el ama o el ama de servicio o una lavandera o "muger que laba la ropa de la casa» (1771-1773), a razón de ocho doblas de salario en 1603-1609 o de 10 pesos anuales en 1773-1781. También se pagaba a quien ayudaba al ama a lavar «la ropa en algunas ocasiones» (1673, 1707-1709) o unas sábanas "por estar enferma la ama» (1780-1781). En 1743-1744 se abonaron dos reales por su trabajo, además del real que cobraron por dejarlo hacer, a las dos mujeres que llevaron a lavar dos quintales de lana para dos colchones a la Huerta Nueva.

\section{EsClAVAS Y ESCLAVOS}

Las esclavas entraban a servir tras haber sido destinadas por sus amos a ese fin -en ocasiones ante la imposibilidad de poder pagar su curación en caso de haber caído enfermas-. En 1603 se inventariaron, entre los animales de carga, dos jumentos y una esclava «negra llamada Andrea que dejó Lucana Hernández, primera muger de Diego de Luxán», vendida más tarde. En 1699, Beatriz Ana Camacho, viuda de Salvador Francisco, cedió al hospital otra esclavita negra de 20 años de edad para que, una vez restablecida, sirviese al mismo o fuese vendida ${ }^{94}$. Los descargos del año 1694-1695 mencionan a la «mulata de la casa» y a Isabel, «esclava de la casa" (suponemos que la misma persona), a quienes se entregaron un par de zapa-

${ }^{93}$ En 1658 se dieron cinco pares de zapatos, por Navidad y Pascua de Resurrección, al sacristán, a las dos amas, moza y vieja, y a las dos «Franciscas», criadas, «Frasquita y la otra». Entre 1669-1672, sirvieron en el hospital las amas Beatriz García y Luisa Enríquez, además de las criadas Francisca, Margarita la Capota, Lorenza y María la Toronja; mientras que entre 1673-1675 lo hicieron las amas Ana Enríquez e Inés de los Reyes y las criadas Ana Gutiérrez, «la Camacha» y Lorenza.

${ }_{94}$ APSSCP: Legajo «Hospital», n. ${ }^{\circ} 11$. 
tos, una toca y un jubón de gordalate. Otras veces los esclavos fueron donados para contribuir con su venta a la curación de los pobres del hospital. Así se hizo en 16731674 con Juan de Lima, «negro que dio de limosna a la casa el yllmo. Rmo. Señor obispo de estas yslas», don Bartolomé García Ximénez. Comprado por el maestro de campo don Miguel de Abreu y Rexe, los 400 ducados de su importe se gastaron en jergones, sábanas y almohadas.

\section{CAPEllanes, SACRistanes y ORganistas}

De la atención espiritual de los enfermos y del servicio de la iglesia y sacristía se ocupaban el capellán, el organista y el sacristán. Al primero, a los beneficiados de la iglesia mayor en su falta o a otros clérigos se les pagaba por las capellanías, memorias y aniversarios, cantados y rezados, fundados por los benefactores de la casa, por las misas de los miércoles, domingos y días de fiesta de todo del año, por las nueve de aguinaldo y por las de los difuntos fallecidos en el hospital. En 1814, los hermanos de la Junta de Caridad acordaron reunir todas las memorias en un solo capellán para que le sirviese de congrua, con la obligación de administrar los sacramentos y auxiliar a los moribundos. El sacristán cumplía, además, función de hospitalero, acompañando al médico y a las amas en las visitas a los enfermos, informándoles de su estado y evolución y ayudándoles a «bien morir», según reglamentó en 1603 el obispo Martínez Ceniceros, quien dispuso igualmente que registrase en un cuaderno todo lo gastado diariamente con los enfermos y con los servidores de la casa en vino, aceite, gallina, carnero y demás. Su salario (ocho doblas en 1610) podía incluir, "por concierto", el sustento o el trigo "para su comer» (cinco fanegas anuales en 1634-1636) ${ }^{95}$. Se le daban los zapatos y disponía de habitación dentro del hospital. El sacristán podía actuar también de limosnero, pidiendo por calles y puertas dentro de la ciudad. Así lo hizo Gabriel de Sosa en 1633-1636.

\section{SePUltureros, MANDADEROS y OTROS SERVICIALES}

Las cuentas de los mayordomos del hospital registran los pagos a diferentes hombres, mujeres, mozos y serviciales de la casa, asalariados o eventuales: al mulato que servía de almocrebe, al mismo por llevar unas «caxas al campo por el arrebato de mayo del año de 1601»; a Catalina González, "por el servicio della y su hijo» Perico; a Gaspar Francisco y al hijo de Pedro Gil, «que sirvió de almocrebe dos meses» (1602); "a la de Pedro Gil y su hijo por el servicio que va hasiendo en la dicha casa»; al «hombre que fue a Los Sauces en servicio del hospital» (1603); al acequiero Bartolomé González Agujetas, retribuido con un salario de 40 reales al año

95 Tras la muerte de Juan de León, su madre recibió 52 reales y medio del salario adeudado por el tiempo en el que había sido sacristán (1632-1633). 
por aderezar y traer el agua al establecimiento (1627-1628); a los mozos que doblaron las campanas la noche de los santos, gratificados con un almud de castańas (1646); a quien iba a buscar raíces y hierbas para pócimas (1669-1676); al peón que plantó calabazas (1648); al que ayudaba a subir el trigo al granero (1810); al mulato que colgaba la iglesia (1634); al Cabrilla por enramarla y a Pedro el Tarcio por armar y desarmar el trono (1789). Un servicial o sepulturero solía actuar de enterrador, de peón y mozo de mantenimiento y reparaciones. A mediados del siglo XVII se cita en numerosas ocasiones al Chanco, apodo de Domingo González, por abrir y cerrar sepulturas, empedrar el patio y la calle, aderezar los cańos del agua, ayudar a colgar la iglesia, traer enseres para las fiestas que celebraba la institución o apalear el grano en el granel. En el siglo siguiente actuó como tal Andrés el Tartano (1756-1789), a quien se le pagaba por quemar la ropa, colchones y camas de los héticos y enfermos contagiosos, sepultar a párvulos y adultos o armar el trono, con el Tareco, para las fiestas (1789). Desde 1800 aparece el «mozo de la casa» o «mozo de calle», a quien el mayordomo hubo de subirle el salario (de dos pesos y cuatro reales a tres pesos al mes) porque no se conformaba con el que tenía antes.

\section{Mampostero o Limosnero}

Para pedir limosna hubo en los primeros tiempos un "mampostero" o «cogedor de limosnas» que, con su animal de carga (jumento o pollino), se encargaba de recoger, en cascos, costales y espuertas, las limosnas en mosto, trigo, centeno y cebada pedidas por las eras, lagares, bodegas y graneles de toda la isla. Con el fin de ahorrar el gasto de su salario y la cebada y paja de alimentar a jumentos y pollinos, el obispo Martínez Ceniceros recomendó en 1603 que se encargara esta tarea a alguna persona de confianza en la ciudad y a los curas y personas devotas en el campo, a las que se podría dar por su trabajo parte de las limosnas que allegasen. En los años siguientes, tal ocupación la ejercieron Pedro González (1599-1602), Juan Rodríguez Pollo, casero, vecino de Tenagua, y Pedro de Acosta (1626-1627); un mozo que pidió limosna en el término de Mazo en 1646; Lorenzo de Zamora (1631-1635), que, en premio por su trabajo, recibía la mitad de lo que los campesinos de daban en trigo, centeno, arvejas, lino, quesos, gallinas, huevos, cabritos o calabazas; además de "otras personas pobres» que recogían pollos, almendras o quesos que luego se llevaban y distribuían en la casa (16331634). En sus constituciones (1782), la Junta de Caridad estableció el nombramiento de un hermano supernumerario en los campos con el cargo de recaudar y remitir las limosnas de los fieles. 
Los gastos del hospital también contemplaban los honorarios del letrado que servía de abogado en los pleitos de la casa (1627-1628) y las diligencias de procurador y notario $(1637)^{96}$. Señalado por el vicario eclesiástico o por el juez, desde finales del siglo XVII se abonaba un salario de más de cien reales anuales al procurador (1697-1699) o al abogado (1735-1738) por su trabajo en los continuos litigios seguidos a causa del considerable número de tributos y rentas impagadas.

\section{LA CASA-HOSPITAL: FUNCIÓN Y ORGANIZACIÓN ESPACIAL}

Como el resto de centros similares del Archipiélago, en planta el edificio seguía el modelo de casa-hospital de estructura claustral o casa-patio y casa-huerta adoptado en las Islas desde principios del siglo xvi. Como una vivienda urbana o un convento, las construcciones de este tipo se estructuraban en torno a un patio o un claustro que articulaba sus diversas dependencias, incluida la iglesia, cuya ubicación, adosada a un costado y paralela a la vía pública, actúa de barrera entre la calle y el interior del edificio, aislándolo del ruido y las molestias del exterior ${ }^{97}$. Así es el caso de la pequeña casa-hospital de Icod de los Vinos, con patio con doble galería al modo de las viviendas tradicionales del Archipiélago, o el de Nuestra Señora de los Dolores de la ciudad de La Laguna, únicos ejemplos conservados. Levantado este último sobre una antigua residencia urbana perteneciente en el siglo XVI al vecino Martín de Jerez, tras la importante reconstrucción experimentada a finales del siglo XVII, presenta un verdadero claustro, con galería baja a su alrededor en todo su perímetro. Esta disposición resulta además análoga a la de los monasterios femeninos de clausura, con templo de una sola nave paralelo a la calle, formando un bloque compacto con el núcleo del claustro y una fachada lateral corrida en la que, como en La Laguna, se abren dos puertas gemelas a semejanza de las iglesias monjiles. Como los conventos femeninos, estas primeras instituciones hospitalarias contaban también con portería y torno; y aunque gozaban de régimen abierto, el orden, recato y silencio que regían su vida interior recuerdan igualmente al reglamento de una casa de recogimiento o de un claustro monástico ${ }^{98}$. Sus muros sirvieron de cárcel a mujeres de existencia desgraciada y, dentro de ellos, buscaron pro-

${ }^{96}$ En 1654 el procurador Antonio de Almeida fue retribuido con 20 reales por un ańo de salario.

97 Pérez Morera, Jesús y Rodríguez Morales, Carlos (2008): Arte en Canarias: del gótico al manierismo, Santa Cruz de Tenerife-Las Palmas de Gran Canaria, Viceconsejería de Cultura y Deportes, pp. 150-154.

98 En 1584, el obispo Rueda mandó que la hospitalera tuviese cerrada la puerta del patio, tanto por la honestidad de los que estaban dentro como por la seguridad de sus bienes. Y en 1629 el vicario de la isla, el licenciado Cosme de Santa María, alertado por los rumores de escándalo, dictó auto 
tección retraídos y huidos de la justicia, cuyos excesos, juegos ${ }^{99}$ y vidas licenciosas dieron lugar a prohibiciones por parte de las autoridades eclesiásticas para salvaguardar la honestidad de la casa. Hasta su desaparición en el siglo XIX, el hospital de Santa Cruz de La Palma conservó su estructura original heredada del siglo XvI, con patio y galerías abiertas hacia el sur. Sus detalladas cuentas e inventarios de bienes, desde 1599 en adelante, permiten conocer sus distintas dependencias, su uso y función, así como el mobiliario y los enseres de una institución de este tipo con bastante aproximación ${ }^{100}$.

\section{IGLESIA}

Es la única edificación que perdura del conjunto, transformada en teatro público a partir de 1866. Del templo subsiste aún su portada principal, con arco gótico apuntado y baquetonado labrado en cantería colorada, y el arco de medio punto de la capilla mayor, en cantería azul. Poseía dos puertas traviesas o laterales, una hacia la calle del hospital y otra hacia el patio interior, conocida, al igual que en los claustros conventuales, como "puerta de Gracias» (1706-1707), precedida de una escalera que salvaba el desnivel ${ }^{101}$. Su armadura de nudillos y tirantes fue contratada el 23 de abril de 1553 -meses antes del ataque de los piratas franceses- por el bachiller Pedro Ortiz, médico, y Francisco de Salazar, hermano mayor y mayordomo, con el carpintero Juan Rodríguez, en precio de 54 doblas ${ }^{102}$. Es probable que desde ese tiempo el campanario consistiese en una simple estructura de madera $^{103}$ de la que colgaba una única campana grande "con su soga con que se tañe a missa", fundida de nuevo o sustituida por otra traída de Inglaterra en 1652. El coro se hallaba en alto, a los pies de la iglesia. «Un órgano grande en la tribuna alta» contaba con mesa, banquillo, caños, fuelles, bastidor, encerado y llaves. Entre 1669 y 1671 se hizo un nuevo coro con escalera de madera, poyos bajo él, puerta, ventana y balcón. Según consta en 1603, había tres «berjas de hierro questán colgadas sobre la puerta de la sacristía de la parte de dentro", a través de las cuales los enfermos podían seguir los oficios religiosos. Otra referencia más tardía menciona

\footnotetext{
para que no se recibiese a ninguna mujer de puertas adentro y ordenó que el sacristán, al que prohibió la entrada, cerrase todas las puertas de la iglesia dada la oración de ayunas.

${ }_{99}$ En 1650 el visitador Diego Vázquez Romero Botello -informado de la práctica de juegos de naipes en el hospital "con mucha yndesencia»- mandó al sacristán que no participase en ellos ni los consistiese, bajo pena de excomunión mayor y privación del oficio.

${ }^{100}$ AMSCP: Legajo 629, n. ${ }^{\circ}$ 1, libro de mandatos e inventarios; inventarios (1603-1713), ff. 218 r.-314 r.

101 Por auto firmado el 10 de diciembre de 1603, el obispo Martínez Ceniceros señaló el derecho de asiento de una vara y dos tercias, en los arrimos que había «desde la escalera que entra del patio del dicho hospital a la iglesia hasta debajo del choro», a María López de Miranda, viuda, a doña Juana de Espinosa, su hija, y a dońa Ana de Espinosa y Vallejo, su nieta.

${ }^{102}$ Lorenzo Rodríguez: op. cit., t. I, p. 327.

${ }^{103}$ En el inventario de 1643 figura «media tizera que está en el canpanario».
} 
la existencia de «la tribuna de la capilla mayor» que, al igual que las fenestras de la misma y el arco de la puerta de la sacristía, fueron pintadas en 1764-1765.

\section{SACRISTÍA}

Situada en la planta baja de la casa-hospital, comunicaba con la capilla mayor a través de una puerta abierta en el lado del Evangelio. Por su ubicación inmediata a la esquina del altar, se mandó tapiar en 1603 y mudar a un rellano que se haría delante de los escalones de las gradas del presbiterio. En ella se encontraba una «talla de tener agua» (1643) o "pila de la sacristía», con su piedra de destilar y jarrito, un aguamanil con su sumidero para el lavado de las manos de los sacerdotes (17461747); una «alacenilla» con los santos óleos que se administraban a los enfermos y moribundos; otra alacena para los cálices y la plata del servicio del culto; un cajón de ornamentos con seis gavetas, sobre una tarima, donde se revestían los sacerdotes; y un mueble con el archivo de la institución.

\section{ArCHIVo}

Como se ha dicho, se hallaba en la sacristía. Integrado por libros, protocolos y legajos de cuentas, relaciones e inventarios de alhajas, bienes y rentas, memorias, obras pías y capellanías, cuadernos y cartillas de tributos, instrumentos y papeles de derechos y escrituras, libros de bautismos de expósitos y de entrada y salida de enfermos, se custodiaba dentro de un cajón de madera, con dos gavetas y una llave en poder del mayordomo, en cumplimiento del mandato hecho por el obispo Cámara y Murga en $1629^{104}$. En la visita de 1686, tras hallar «mucha variedad de materias que se comprehenden en su administración", el licenciado Pinto de Guisla puso en mejor forma sus libros, protocolos y papeles, haciendo libro de visita particular del hospital para poner con más extensión todo lo concerniente a la institución. Entre 1699 y 1702 se dieron 100 reales al franciscano fray Domingo Ventura para un hábito en gratificación "por el trauajo de hacer y poner en orden los protocolos de las escripturas de la cassa». En 1774-1779, el licenciado don Tomás de Abreu cobró otros 400 reales por inspeccionar y cotejar los libros de relaciones y cartilla de tributos, «sin embargo de que muchas escripturas por lo encadenado de la letra dieron mucho trabajo». En 1800 se hizo el Protocolo 9. ${ }^{\circ}$ y un nuevo Libro de Relaciones, a los que se añadieron abecedario y forros de badana negra, al igual que al Libro de Relaciones viejo. Por formar una nueva cartilla de tributos se pagaron cuatro pesos corrientes al sargento Soisfans en 1812. En tiempos de amenaza de invasión, el archivo, al igual que las alhajas de la iglesia y de la Virgen, era trasla-

${ }^{104}$ En 1639, el licenciado Gaspar Fernández Camellón se descargó con 628 maravedíes por el costo de «un caxón para los papeles». 
dado al campo. Así se hizo «quando el rrebato de mayo del año de 1601» y durante las guerras anglo-españolas, en 1743-1744, en 1761-1763, en 1779-1780 y en 1797. Por mandato del vicario, en 1779-1780, se compró una caja para «llebar los papeles y otras alhajas de la casa a San Pedro por las guerras». En 1743-1744, hubo que hacer una nueva llave para el archivo al negarse el anterior mayordomo, don Juan Viñoly, cuyas cuentas fueron contravenidas, a entregar la que tenía.

\section{PORTERÍA}

Zaguán de entrada abierto hacia la "calle de la Cuna», con una puerta «de fuera" y otra que daba al patio. En ella se hallaba instalado un torno o tornillo giratorio por donde eran echados los nińos expósitos ${ }^{105}$. Contaba con una campana para llamar a los sirvientes de la casa ${ }^{106}$ y una rueda con campanillas y soga desde 1784 con el mismo fin. Entre 1669-1671 se fabricó una portería con su empedrado, sardinel de cantería en la puerta de la calle y una cruz. En 1743-1744 se colocó una nueva puerta, con su postigo embisagrado, fechadura y argolla, construida por el carpintero Carlos de los Reyes y su mozo con media docena de tiseras y otras tantas tablas de solladío. En 1764-1765, se pintó el «escudo de la Virgen» sobre la puerta principal, así como «la cruz de la capilla mayor que está por la calle». Frente a la residencia de don José María Fierro, hacia la calle del Hospital, existía además una inscripción, pintada en rojo, que elogiaba a esta familia como bienhechores de la institución ${ }^{107}$.

\section{Cuna de EXpósitos}

Situada en una pieza muy reducida contigua a la sala de enfermos varones, en esta habitación el ama o las amas de leche atendían a los recién nacidos hasta su traslado al campo para ser amamantados por las amas de cría. Para ello había una cuna fija en el suelo, como consta en 1657. Su ubicación en el mismo cuarto o sala donde se curaban los hombres enfermos, «respirando los bapores fétidos de estos y sus enfermedades», urgía su traslado a otra pieza más acomodada, según informó la Junta de Caridad en 1784. La continua asistencia de día y de noche del ama de leche, servicio que debía ser desempeñado por mujeres de no mucha edad, obligaba a compartir «un mismo quarto con hombres de todas hedades, a veces solos» que hacía poco menos que imposible guardar "por los enfermos, expecialmente en algunas indisposiciones, la composición y decencia que se deue delante de personas de otro sexo». La falta de caudales de la institución impidió todo cambio. Tal disposición, nula ven-

\footnotetext{
105 Las cuentas de 1672-1676 anotan el gasto de 34 reales que «hiso de costo el tornillo donde se echan los niños».

${ }^{106}$ En 1673 se inventariaron una campana grande en el campanario y otra mediana en la portería.

107 Lorenzo Rodríguez: op. cit., t. I, p. 93.
} 
tilación, reducida a su única puerta, y su escasa separación del salón de enfermos, del que apenas distaba tres o cuatro varas, fueron algunas de las razones que el párroco don Manuel Díaz expuso para justificar el traslado del antiguo hospital al convento exclaustrado de Santa Clara.

\section{ENFERMERÍAS ALTA Y BAJA PARA MUJERES Y HOMBRES}

Desde el siglo Xvi el hospital contó con dos enfermerías para hombres y mujeres respectivamente, conocidas también como salas altas $-\mathrm{o}$ "sala grande»- y baja. Su separación por sexos obedecía a criterios morales, de modo que hombres y mujeres debían curarse en diferentes enfermerías aunque estuviesen casados. Si el marido estaba enfermo, podía ser atendido por su mujer durante el día. En caso contrario, sólo se permitía al esposo visitar a su cónyuge en publicidad y en algunos días ${ }^{108}$. En 1580 se mandó cubrir con tablado - por estar «muy sumida» - «la pieça vaxa del dicho hospital en que se curan las mugeres enfermas por razón de no estar solada, lo qual es detrimento para su salud». Décadas después, en 1603, el obispo Martínez dispuso que la parte del aposento del granel, en la planta alta, que miraba hacia el barranco de los Dolores, fuese reconvertida en enfermería de mujeres con una división o tablado de madera que llegaría hasta el techo ${ }^{109}$. En ambas enfermerías existían, en 1603, 13 barras

108 AMSCP: Legajo 629, n. ${ }^{\circ}$ 1, libro de mandatos e inventarios; mandatos del licenciado Gabriel de Sarabia (1591), f. 14 v. y de don Francisco Martínez (3 de septiembre de 1603), ff. 22 r.-22 v.: «Otrossí porque sería gran peligro y offenssa de Nuestro Señor que onbres y mujeres se curasen juntos mandamos que siempre aya dos enfermerías, vna donde se curen los onbres y otra donde se curen las mujeres, los quales en ninguna manera se junten so pena de quel mayordomo los pueda excluir del dicho hospital quando viere que le paresiere». "Otrossí que si vinieren a curarse a ell dicho hospital algunos pobres que dijeren ser casados que no les tengan por tales hasta que se sepa clara y ciertamente que lo son y, en caso que lo sean, si anbos vinieren enfermos se curen en diferentes enfermerías, el marido en la de los onbres y la muger en la de las mugeres; y si solo el marido estuviere enfermo no se permita que la muger quede de noche con él, sino solamente de día acuda a curar la enfermedad de su marido; y si fuere la muger enferma el marido no asista en el dicho hospital ni a curar su muger ni otra cossa, salvo que la pueda entrar a visitar de día y publisidad algunos días».

109 AMSCP: Legajo 631, libro de cuentas de la casa-hospital (1602-1649), cuentas de 11 de septiembre de 1603, f. 31 v.: «Yten que la enfermería baja donde se curan las mujeres se haga en alto en el aposento del granel, hacia la parte de la ventana del barranco, atajándola por junto a la puerta sigunda questá de frente de la ventana primera, hasiendo a la entrada un cansel algo anchurosso por donde se pueda entrar a la dicha enfemería; y el atajo se haga por el remate del, de manera que la bentana questá de frente de la dicha puerta no quede dentro de la enfermería sino del aposento que queda después del atajo, el qual serbirá de granel, ques bantante para ello, pues tiene puerta por ssí y el fresco de la bentana le ayudará para conserbarsse. Y aunque es verdad que la dicha enfermería trasada en la manera dicha tiene otra puerta más adelante por donde se le pudiera dar entrada, teniendo atencçión a que ocuparía mucho de la dicha enfermería, y lo que más es que no quedaría la enfermería de manera que pueda correr el ayre por toda ella den quando en quando para su linpiesa, lo qual queda transádose en la manera dicha, pues de la dicha la puerta hasta la bentana del barranco queda vien corriente el ayre. Y adviértese que el atajo que se ubiere de haser de la dicha enfermería en la manera dicha a de ser que llegue a la punta del techo porque'l ayre de la enfermería no pase a el dicho granel». 
de camas con sus bancos y 19 colchones entre nuevos y viejos ${ }^{110}$, así como un catre en el que dormía el ama, dos bancos de cama, dos bancos, dos altares de madera, una caja con botes de aceite, una caja vieja en la enfermería baja y dos tinajas grandes para el agua. Entre las cosas de colgar se citan además, en 1618, cuatro guadamecíes dorados con figuras, ya "muy viejos, que siruen a los enfermos». Anexo a la enfermería de los hombres, se hallaba «el quarto de oir misa los conbalecientes en la sala baja de enfermos» (1764-1765).

\section{Cuartos de unciones, purgas y sudaderos}

Con la limosna de 500 ducados que dejó el capitán Juan de Valle se edificó un cuarto «en que los enfermos tomasen sudaderos y ser purgados sin enfado de otros», construido entre 1610 y 1612, en tiempos del capitán Andrés Maldonado. Las referencias a la reparación del tejado del cuarto o aposento de las unciones (17791780) y a la ventana existente debajo de él indican que se trataba de una pieza alta levantada sobre la llamada «lonxa de las unciones». Iluminada con una única ventana, un bastidor de lienzo (coleta), guarnecido con hiladillo y tachuelas y renovado cada cierto tiempo (1735-1738, 1746-1747), permitía oscurecerla cuando era necesario $^{111}$. Sogas y sábanas servían también para aislar y «tapar a los de unciones» (17051706). En 1797 se habla del "cuarto viejo de las unciones» ${ }^{112}$. Con el objeto de que cada sexo tomara las unciones por separado, para entonces ya se habrían construido dos pequeñas "piezas de uncionistas» en la cabeza de cada una de las enfermerías de hombres y mujeres, con una única salida a las mismas salas.

\section{ApOSENTO DE POBRES MENDICANTES, SALA DE HÉTICOS Y CUARTO DE LAS RECOGIDAS}

Destinado a recoger a los "pobres de solemnidad» o "pobres vergonzantes», en 1610 se hallaba tan sucio que «basta el sólo a infiçionar a el hospital». Para evitarlo en lo sucesivo, el visitador Gaspar Rodríguez del Castillo ordenó que los mendicantes que pernoctaban en él, cada uno por su orden, lo barriesen y regasen todos los días, bajo pena de expulsarlos de la casa. Debe de tratarte de la pieza denominada con posterioridad como el «aposento hacia el barranco» o "quarto de los éticos que cae al barranco» (1786). Las «lonjas de los éticos» o héticos (nombre con el que se conocía a los pacientes de tísis o tuberculosis) se compusieron con barro en 1692-1694. En 17731774 se encaló en parte, albeó y se remendó el «suallado» del mismo. En esa fecha se

${ }^{110}$ En 1648 se enumeraron 20 colchones «que tienen los mendigantes y los demás enfermos y sachristán».

${ }^{111}$ En 1757-1758 se pagó un real al maestro Leonardo Quintero «por conponer el bastidor del quarto de los vnsionados que cayó a la calle y se ronpió».

112 En 1796 consta la composición de la ventana del «quarto viejo de unciones» y en 1805 el «alveo de los quartos de unción». 
hizo un oratorio con sus puertas para la sala de héticos, en lugar de la mesita inmunda en la que hasta entonces se ponía «a Su Majestad» sacramentada con mucha indecencia, cuyo importe fue de 192 reales en madera, hierros, oficial, pintura y forro de papel pintado para su interior. Con posterioridad se cita la pieza o cuarto «de las recogidas» y el traspatio del mismo nombre, así como los trabajos de limpieza, reparación del tejado y composiciones verificadas en 1797 y 1810.

\section{CuARTOS DEL AMA, AMA DE CRÍA Y SACRISTÁN}

Para el personal hospitalario existían algunas habitaciones independientes. Si bien el ama u hospitalera dormía en un principio en un catre dentro de la enfermería con los demás enfermos, con posterioridad se documentan la «lonja de la ama» y la «casa del ama», cuyo suelo fue «entullado" por estar hondo en 1669-1671; así como el «cuarto del ama enfermera» (1764-1765) y la fechadura y llave del «cuarto del ama de los enfermos» (1774-1779). En 1776, se fabricó de nuevo, al mismo tiempo que el cuarto del sacristán, el de la sobrescalera, la cocina y el granero, obras en las que, además de cal, arena, tierra, barro y tablas de forro y solladío, se emplearon 31 cargas de piedra volcánica del Zumacal (Breńa Baja) para los tabiques. El «aposento de la escalera y patio» o "cuartito sobre la escalera", cuya puerta y una ventana se abrieron en 1669-1671, fue tejado y encalado de nuevo en 1773-1774 (por amenazar ruina), con la cal que el mayordomo procuró de algunos devotos. Para el ama de cría se hizo un repartimiento en la sala de enfermos en 1773-1774. En la puerta del cuarto de la misma ama se pusieron en 1800 unas quicialeras y en el sardinel de la entrada unas piedras que fueron traídas del barranco por el boyero en 1802. En el cuarto del sacristán se colocó en diciembre de 1812 una ventana en la que se utilizaron varias tablas de solladio y aforro.

\section{Sala «De Profundis»}

Utilizada como velatorio de los cadáveres. Situada habitualmente -en conventos y monasterios- en la antesala del comedor, toma su nombre del primer versículo del salmo 130 (129): «De profundis clamavi ad te, Domine». Su existencia consta desde 1767, fecha en la que el presbítero Antonio de los Reyes Dutre y Loreto, capellán del hospital, destinó en sus últimas voluntades testamentarias una mesa grande de pino que tenía en la sala grande de su casa para que se colocase en la «sala de profundis para que sobre ella se pongan los cuerpos de los pobres que murieren en dicha santa casa a fin de que se traten dichos cuerpos en su sepelición con la mayor decencia que pueda la pobreza de dicha casa sufrir ${ }^{113}$. Un farol, alimentado con aceite de oliva, iluminaba durante la noche el "quarto de Profundis»,

${ }^{113}$ Pérez García: op. cit., p. 52, nota 70. 
según se dice en 1768-1769. Otras referencias recogen los pagos al sepulturero "por limpiar y quemar todo lo inútil que estaba en el quarto de Profundis» (1797) y de un real por una llave para el mismo cuarto (1802).

\section{Cocina y COMEDORES}

A lo largo de los siglos, las reparaciones y composiciones de la cocina fueron continuas. En 1649, los albañiles Manuel de Párraga y Bartolomé Sánchez Agujetas, ayudados por el Chanco y varios peones, aderezaron «la cosina y jorno» e hicieron tres «fornallas» o fogones para guisar; entre 1669-1671 se empedró, se enrajonó, se abrieron dos ventanas y se enterraron las tinajas; en 1738 el maestro Amador Fernández de Fuentes realizó otra composición con los cantos que trajeron los arrieros; y en 1746-1747 se le puso suelo y enlosó. En 1776 fue reedificada de nuevo y se instaló una canal entre la pared de la cocina y la del granero; en 1788 se colocó una tabla de pino en el basal de la cocina que se había caído y se remendaron las tapaderas de las tinajas; y en 1811 el maestro Agustín, herrero (Agustín Hernández Carmona), hizo dos gradillas para los hogares. Excepcionalmente y en fecha tardía, se citan los «comedores» (cuya ubicación no se indica) y su composición en las cuentas rendidas en 1810 .

\section{DESPENSA Y CUARTO DE LA HARINA}

$\mathrm{Al}$ igual que en el resto del edificio, los enjalbegados con cal garantizaban su higiene y desinfección. En 1639-1640 cuatro albañiles se encargaron de encalar la despensa durante tres días, asistidos por tres peones a los que se les gratificó por su trabajo con «tres quartillos y medio de vino que beuieron». Sobre la pared enlucida se puso por entonces una tabla para proteger las conservas de los ratones. Aparte de una tinaja grande para el agua que había en el patio, existía otra en la despensa (1643). Además del azúcar y las conservas, en ella se guardaban el arroz y las legumbres, las papas, el aceite, el jabón y las velas de cebo. El aderezo del «cuarto de la harina» se menciona en 1655 .

\section{HORNO}

El obispo Martínez recomendaba que no se amasase el pan en la casa con el fin de ahorrar los costos de leña necesaria para cocerlo «y el sustento y salario de las mujeres que lo amasaren y en lo que tomaren de ello a su voluntad no siendo persona de confiança». El trabajo de amasar el pan era una de las funciones del ama, de modo que en 1632 el mayordomo del hospital entregó la "sábana de el pan», dos lebrillos y tres bancas del servicio de amasar, un cedazo, un «quarto de madera en que se echa el trigo" y un "tablero en que echan el pan» a Francisca Pérez. 55 reales se gastaron en 1643 en abrir un bocal nuevo de cantería al horno, cubrirlo con 
cal por fuera, y en barro y peones. En 1657-1658 se levantó de nuevo con ladrillos, barro y cal. Un costal, un harnero y una pala para el horno se compraron en 1669 por siete reales y medio. En el siglo siguiente, el pan se dejó de amasar y hornear en la casa y desde 1738 hay noticias del acarreo del trigo desde el granero del hospital a la casa de la panadera.

\section{Camarín de la Concepción}

Su situación resulta difícil de ubicar, pero fue fabricado en 1776 por el pedrero Domingo de Paz Cisneros al mismo tiempo que, con sus oficiales y peones, reconstruyó el granero, la cocina, el cuarto del ama, el del sacristán y el de la sobrescalera. En él se vestía y se guardaban las alhajas de la imagen de la Inmaculada Concepción, cotitular de la casa-hospital, que desde el siglo Xvi poseía un suntuoso ajuar. Años después constan los gastos de una llave para la puerta del camarín (1796), albeo con cal, fregado y un esterado con estoperoles para el mismo (1802).

\section{Granel o granero}

Trasversal a la sala o enfermería grande, el «aposento del granel» se extendía en la última planta, paralelo a la nave de la iglesia, en dirección norte a sur hasta caer sobre el barranco. En él se almacenaban el grano (trigo y centeno) y las legumbres (garbanzos) procedentes de las rentas y tributos y de las limosnas recogidas por el campo y con los que se sustentaba tanto a los enfermos y "pobres vergonzantes» como a los sirvientes del hospital. Si las condiciones lo permitían, se alquilaba para contribuir con su renta a la maltrecha economía del establecimiento ${ }^{114}$. 36 fanegas de trigo, a diferentes precios, se entraron en 1666 en el granero para el gasto anual de la casa, de las que sólo sobró una. Cosechado en Tijarafe, Puntagorda, Garafía, Barlovento, Puntallana o Buenavista, el trigo procedente de los tributos en grano, de las compras o de las limosnas debía ser acarreado desde el muelle hasta el hospital para ser «engranelado» en el granero, transporte que realizaban negros y esclavos de ambos sexos ${ }^{115}$. Para convertirlo en harina, se llevaba a moler a casa del molinero, a razón de un real por fanega (45 reales en 1698-1699). El granel servía además como trastero para guardar diversos objetos: una pipa vieja y un baúl grande, cuartos pequeños y medianos para harina y legumbres, botijas vacías, servicios y platos blancos, platos de estaño, bacinillas de cobre, escobas, varias cal-

${ }^{114}$ En 1612-1613 se alquiló dos veces.

115 Dos reales y dos cuartos se pagaron «a las negras que truxeron del muelle a el granero del hospital» las 12 fanegas de trigo enviadas de Barlovento por Pedro Yanes de la renta de la cosecha de 1647; y ocho reales por el alquiler de 18 costales a la mujer de Alonso Vargas, mareante, para traer de Los Sauces el trigo de la limosna del obispo «y al boyero y negra que lo traxo al dicho hospital y lo subió desde la puerta al granero». 
deras de cobre, una barra de cama o un canal de tea se almacenaban en 1644 «en el granel del barranco». En 1650, el visitador Romero Botello mandó hacer una reja de madera en la puerta alta del granel que salía al osario con el fin de dejar entrar el aire "para la conserbasión de el pan que se echare en él», así como enladrillar la sala que servía de granero. Ese mismo año, el carpintero Luis de Francia y su hermano se encargaron de mudar de sitio el tablado del granel y remendarlo con «tablas de solladio». Se tenía especial cuidado en cerrar la pieza con llaves, cerraduras, candados y cadenados con la intención de evitar sustracciones. Para evitar que se corrompiese con el agua de lluvia o se lo comiesen gorgojos y ratones, se trastejaba regularmente y el grano se apaleaba ${ }^{116}$. Con el mismo fin se ponía arena «deuajo del trigo que se recoxe en el granero de la cassa», como la que un peón trajo en 1788. Las mermas por unas u otras razones no eran despreciables. En 1746-1747 se perdieron cuatro fanegas de trigo, «así en las medidas como por las sabandijas que ai en el dicho granero"; y otros cuatro celemines en 1813 «por estar el granero lleno de agujeros", además de una fanega y media "del que vino por el mar tan mojado que no bastaron precauciones para libertarle del gorgojo». Para limpiarlo de roedores se hizo una ratonera en 1796.

\section{BODEGA}

Su parco mobiliario consistía en cajas de madera de pino y en botas, cascos y pipas donde se encerraba el vino destinado al consumo de la casa y para unciones y diferentes remedios en tiempos de frío y lluvia. Para recoger las limosnas en mosto colectadas por los lagares del campo, existían en 1603 tres cascos de botas.

\section{LONJAS}

Bajo esta denominación se conocen aún en la isla las salas bajas utilizadas como depósitos y almacenes. Hacia la calle de la Cuna se hallaba la «lonja de las unciones», llamada así por estar debajo del cuarto del mismo nombre. Alquilada desde 1612 por el hospital ${ }^{117}$, disponía de una puerta frente a la casa de don Juan de Guisla (actual Díaz Pimienta, n. ${ }^{\circ} 10$ ), cerrada a «a piedra y barro» en 1743-1744 por el maestro pedrero Domingo Fernández Crespo ${ }^{118}$. Por entonces se puso un cerrojo

116 En 1647-1648 se pudrieron cinco fanegas de trigo «por auerse llouido el granero y lo que los ratones y gorgojo comieron». En 1651 se dio un real al Chanco, servicial de la casa, por apalear «el trigo en el granel».

${ }_{117}$ En 1612-1613, la casa-hospital recibió cinco reales por el alquiler de un mes «del quarto nuevo de la lonxa de las unsiones» y otros 48 que pagó el prioste de la cofradía, Andrés González, por el mismo concepto.

118 En tal fecha se pagaron 17 reales y dos cuartos «a el Crespo por serrar a piedra y barro la puerta que estaba debajo del quarto de vnsiones». 
«en la puerta nueva de la sala de abajo que entra en la lonja donde están los cajones de las andas», que seguramente debe ser la misma. Por ella pasaban las cañerías que surtían de agua a la casa en dirección a la cocina y al patio. Las cuentas de 17731774 mencionan los gastos de limpiar tres lonjas que estaban llenas de estiércol.

\section{Caballeriza y LeÑERA}

Las cargas de leña que se gastaban en la casa y las limosnas de vino y trigo recogidas en eras y lagares se transportaban a lomos de pollinos y asnos, aposentados en la caballeriza. Allí había un pesebre y una pila para el agua, dos machados para cortar la leña y un hacha pequeña para partirla, un balde de palo con arcos de hierro para lavar, otro balde de madera y una bacía de azófar mediana «en el corral y la caballerissa». Una «jumenta parida que son dos», macho y hembra, una de las cuales «se derriscó», se inventariaron en 1603. El obispo Martínez advirtió en contra de tener "pollinos que gasten sebada y paja" y de ministros o mamposteros para recaudar las limosnas ${ }^{119}$. Carbón, tea y leña se empleaban como combustible para hornear el pan, para calentar las dependencias y el agua para bañar a los enfermos. Para su suministro, se admitía que algunos tributarios, por su pobreza, abonasen sus pagas en cargas de leña y costales de carbón, como es el caso de varias mujeres, viudas y pobres que figuran en las cuentas de 1654 .

\section{Patio o COMpÁs}

Denominado como claustro en algunas ocasiones ${ }^{120}$, el hospital carecía de un patio como tal. Con planta en L, presentaba en el piso superior una antesala o vestíbulo delante de la "sala grande» de la enfermería ${ }^{121}$, abierta hacia el sur con un corredor alto con pies derechos y balaustres torneados ${ }^{122}$, que, tras el traslado del hospital al convento exclaustrado de Santa Clara, fue cerrado con un tabique de obra enlucida y ventanas acristaladas en 1851, en lugar del «embalaustrado» que existía. A la izquierda de la puerta de entrada se situaba la escalera, también con balaustres torneados. La planta baja, empedrada con guijas de playa o callaos ${ }^{123}$ (guijarros marinos con los que se hacían dibujos en los pavimentos) que formaban un "paseo", poseía unos poyos o

119 Las cuentas de 1599-1602 recogen los gastos de tres fanegas de cebada, paja y su acarreto para las bestias de la casa, una albarda, un látigo y el herraje de las cabalgaduras de la casa.

${ }^{120}$ En 1746-1747 un oficial de pedrero se ocupó de albear el «claustro alto» y "claustro bajo».

${ }^{121}$ En 1653 se pusieron dos tirantes de 24 pies en la sala de los enfermos y una canal entre la sala grande y el corredor del mismo largo, sacada de una casa caída en el callejón de la cárcel perteneciente al capitán Antonio de Lugo y Peña.

${ }_{122}$ En 1756-1757 se labraron 18 balaustres torneados que se encargaron para el corredor de la casa y la baranda que subía al coro, con dos tijeras de tea.

123 En 1669 se emplearon 15 cargas de «hijas» en empedrar el patio. 
parterres para hierbas medicinales ${ }^{124}$, un escaño y una tinaja grande para el agua. En tiempos del capitán Nicolás Massieu (1618-1620) se empedró y se hizo una latada o emparrado sostenido por maderos. Las molestias ocasionadas a los pobres enfermos por el ruido de voces y rińas de las «muchas personas» que acudían al patio de la casa hicieron que el obispo Arzolorás y el licenciado Aceituno prohibieran en 1571 y 1576 que se llevasen a lavar «ropas al conpás del dicho hospital», bajo pena de aplicar la ropa a los pobres del hospital.

\section{TANQUe, PILA, ARCADUCES Y CAJA DEL AgUA}

Dentro del patio se encontraba el estanque o "tanque de la fuente» $y$, a su lado, la pila del agua, formada, si atendemos a lo dispuesto por el obispo Martínez Ceniceros, por un artesón grande de tablas de madera de tea donde se lavaba la ropa de los enfermos ${ }^{125}$. El mismo mitrado mandó empedrar el sitio del tanque de la fuente, suprimiendo la pared que estaba en medio para darle mayor anchura y levantando la corriente para que el agua «que en él cayere corra con fasilidad al arbollón para que no se detenga en dicho sitio». Canales de madera de tea conducían el agua desde el tanque hasta la pileta destinada a esta última y hasta una tinaja grande, como consta en 1746-1747 y en 1757-1758. El suministro de agua fue siempre una prioridad en el establecimiento hospitalario, para lo cual se empleaban arcaduces y cańos de barro cocido, metal o, con más frecuencia por su menor costo, canales de madera de tea enterrados, que conducían la corriente hasta el estanque. En 1584 se dispuso pasar la acequia por el solar que se había comprado a Juan de Monteverde "y se quite de la enfermería porque viene mucho daño a los enfermos y se podrá aprouechar más agua». Para evitar «los muchos gastos» que cada año se invertían en arcaduces y oficiales, el obispo Martínez mandó encañar el agua dentro de vigas de tea fuertes, buenas y cubiertas de tablas, recias de desclavar, sepultadas bajo la tierra lo suficiente "para que estén cubiertas y el agua venga más fresca». En ocasiones se hicieron contratos específicos con los acequieros para garantizar el abasto. Por escritura otorgada en 1619 ante el escribano Tomás González, Bartolomé González Agujetas se comprometió a mantener limpios y compuestos, a lo largo de un año y medio, los cańos y arcaduces por donde venía el agua a la casa-hospital, «de manera que syenpre y de ordinaryo, de día y de noche, esté corriendo por los dos cañonsyllos que están en el tanque que recoge dellos el agua en el dicho ospital». Para ello se le darían, además de toda la cal necesaria para los reparos, 184 reales por su trabajo

${ }_{124}$ En 1649, los albañiles Manuel de Párraga y Bartolomé Sánchez Agujetas se ocuparon de bajar el tanque, aderezar los caños, empedrar el patio y «jaser el poio de las ierbas».

${ }_{125}$ AMSCP: Legajo 631, libro de cuentas de la casa-hospital (1602-1649), cuentas del 11 de septiembre de 1603, f. 31 v.: "Yten que se haga una pila y se ponga junto al tanque de la dicha fuente para labar los paños del dicho hospital, la qual sea grande y bien hecha, de manera que no se le salga el agua y anssimismo aya una tabla rezia de la dicha tea donde se estrieguen los pańos porque la piedra que para esto suele hauer los rronpe mucho». 
y un barril de vino al cabo de un año ${ }^{126}$. En 1632-1633 se trajo de nuevo el agua al hospital después de "más de 18 años que no venía». Realizada por mano del mismo acequiero, en la obra se emplearon 303 caños, a real cada uno; además de otros 80 que se dieron sin costo, cal, zulaque, «clavos, ferraduras, tijeras, rallos» y plomo. Otros 20 ducados fue preciso pagar al capitán a guerra Bartolomé de Frías por dejar venir hasta su caja, en el barrio de Jorós, «el agua con la que él traya». Desde la puerta de su residencia, conocida como la "casa de la azotea» (actual n. ${ }^{\circ} 14$ de la calle Díaz Pimienta), los caños continuaban hasta la lonja del hospital y de allí al tanque por los conductos de la cocina ${ }^{127}$. Las reparaciones eran constantes y en 1757-1758 fue necesario poner 20 varas de canales de tea, cubiertas por tres tablas de «sualladio para cobijas», en el callejón de José Canales, «donde se consumía toda l'agua por estar los condutos rotos y se minaba a las cassas de la asotea, sin llegar ninguna a la santa cassa». Se arreglaron también y «azulacaron» la caja de Jorós, el tanque del patio, los conductos de la cocina y la lonja interior. En 1773-1774 se volvió a abrir todo el callejón de Canales para traer el agua desde la casa del lomo, «que estubo más de un mes sin llegar", de manera que se resumía por la calle y se formaba un charco entre el hospital y la vivienda del sargento mayor don Santiago Fierro. Se hizo de nuevo la cajita del agua en Jorós, a mitad con don Melchor de Monteverde, y se colocó otro canal en la lonja. Poco tiempo después (1774-1779), se compuso la cañería desde la casa de don Domingo Monteverde hasta el tanquito del hospital, en el que se fabricó una cajita con el fin de repartir el agua para lavar la ropa de los enfermos. Además de la cal, en los arreglos de canales, conducciones, tanques y cajas de agua se utilizaba brea, lienzo, lino, esparto y zulaque (mezcla hecha con cal, aceite, cebo, huevos, estopa o lino) para tapar las juntas. Las cañerías se limpiaban con sogas de esparto (1675-1676). Durante los cortes de suministro, el agua se traía en un barril, como el que se compró para uso del aguador Miguel de Oro en los meses de junio, julio y agosto de 1704, "que faltó y no venía a la casa».

\section{NeCESARIA O CUARTO COMÚN}

El cobertizo con las letrinas se hallaba en el patio, próximo al tanque de agua. En 1603 el obispo don Francisco Martínez mandó hacer dentro del patio «un atajo» de tablado con su cobertizo y puerta de madera, al otro lado del osario, en lugar de las necesarias, para que los que las usasen estuviesen cubiertos y no pudiesen «ser bistos porque assí conviene para la linpiesa del dicho hospital y en él se hará su nesesaria de manera que se pueda limpiar con el corriente del agua del dicho tanque». Entre 1669-1671 se hizo un nuevo osario y un huerto con la «necesaria». Estaba

126 AGP: PN, Escribanía de Tomás González, caja n. 11 (22 de marzo de 1619), f. 422 r.

127 En 1650 se emplearon una fanega de cal, un cuartillo de aceite y lino en aderezar los caños desde la puerta del licenciado don Simón de Frías Coello, propietario de la «casa de la azotea», hasta «la lonxa del hospital»; el trabajo fue ejecutado por Marcos Méndez Rapado y el citado Bartolomé Agujetas con la ayuda de un negro y un peón. 
adosada a la pared del granero y para llegar al «quarto común» había que atravesar un pasadizo con una puerta exterior y otra interior. Fabricado con frágiles paredes de tabiquería con «armadura» o entramado de madera y relleno de obra ligera, en 1787-1788 el viento derribó un tabique del cuarto común, que fue reconstruido por un maestro pedrero y un carpintero con cal y tablas de madera.

\section{Osario}

En esta fosa común, situada en el patio, junto a las necesarias y frente a la salida de la puerta alta del granel, se depositaban los huesos de las numerosas exhumaciones que se practicaban en la iglesia y su cementerio. Sólo en dos años se abrieron y cerraron 58 sepulturas para los pobres enfermos muertos en la casa en 1692-1694; y otras 27 en el año siguiente de 1695-1696. Según el obispo Martínez Ceniceros, se enterraban «muchos pobres y no solamente los que mueren en él sino otros de fuera y muchos negros, esclavos y mulatos, de lo qual se sigue estar sienpre la iglesia ocupada con cuerpos muertos y mui desolada». Para evitar que el templo se desenladrillase en poco tiempo, dio orden para que todos los enterramientos de externos pagasen la limosna de volver a enladrillar la sepultura. Aconsejó además hacer otra fosa común o

carnero al remathe de la iglesia, que si fuere menester salga la bóbeda al simenterio o de la manera que fuere más a propósito, en el qual se podrá enterrar la más de la gente que se entierra en el dicho hospital, pagando la limosna conbeniente y la cal que será necesaria echar sobre los tales cuerpos para que se consuman y no causen algún daño, lo qual se propondrá en el cabildo el hermano mayor y los demás hermanos para que allí se replique y resuelban lo que más conbiniere ${ }^{128}$.

Una pella de cal y un montículo de tierra se apilaban en el patio en 1644 para el aderezo «del carnero», además de 175 tejas. El patio sirvió también de cementerio, de modo que entre 1774 y 1779 se enterró a varios párvulos, no bautizados, que habían sido echados, ya muertos, en el torno.

\section{Corral de AVES y PALOMAR}

Carne y caldo de pollos y gallinas se servían habitualmente a los enfermos para su recuperación, parte de ellos aportados por los tributarios. Informado de sus inconvenientes, en 1580 el licenciado Pedro del Castillo, visitador, mandó deshacer «el palomar de palomas».

128 AMSCP: Legajo 631, libro de cuentas de la casa-hospital (1602-1649), cuentas del 11 de septiembre de 1603, f. 33 r. 
El suministro de agua corriente hizo posible la limpieza y curtido de pieles, a pesar de la suciedad y el ruido que generaban. Por esta razón, en 1576, el licenciado Aceituno prohibió lavar y tender cueros en el patio del hospital. Un siglo después, en 1747-1748, se instaló una tenería por cuenta de la casa para la fabricación de cueros, que se volvió a aderezar en 1754-1755.

\section{Puerta del barranco o puerta trasera}

Al patio se podía acceder también a través de «la puerta del barranco» ${ }^{129}$ 0 «puerta trasera» ${ }^{130}$, abierta en el muro que hacía ángulo con la portada principal de la iglesia, orientada hacia el barranco de los Dolores. Ambas fachadas formaban un pequeño atrio delantero, compás o cementerio, tal y como se ve en una antigua fotografía tomada en 1857, en el punto conocido actualmente como "La Pérgola». Promediado el siglo XVIII, esta entrada secundaria fue reconstruida en forma de portada de sillería coronada por una espadaña de cantería, todo ello fabricado a «fundamentis» por el coronel Felipe Manuel Massieu de Vandale ${ }^{131}$.

\section{MOBILIARIO, MENAJE Y ENSERES}

Anafres o braseros de cobre, asadores de hierro, tachas y calderas de cobre y azófar, cucharas y cucharones, almireces con sus manos y candiles de hierro constituían el ajuar de la cocina, además de un armario de palo para la losa, un peso de garabatos, una banca de amasijo y dos lebrillos de amasar citados en 1603. En ella

${ }^{129}$ Las cuentas de 1640-1641 recogen los gastos del «muro de la puerta del barranco y en la escalera de cal del campanario y puerta del patio». Para ello el capitán Juan de Monteverde dio de limosna 50 quintales de piedra de cal, empleada en «la obra de la iglesia, coro y patio y sala de el barranco y en los tejados y campanario».

${ }^{130}$ En noviembre de 1651 el cantero Juan Sánchez Carmona recibió 14 reales por hacer «el escalón de la puerta tracera».

131 Archivo Lugo-Viña y Massieu (Tenerife): Información de las dádivas hechas por don Felipe Manuel Massieu de Vandale (1774). Declaración de don Diego de Vargas Machuca, beneficiado de la iglesia de El Salvador, de fecha 28 de mayo de 1774: «Al nono dijo que es verdad y le consta que dicho Señor fabricó una grande portada de sillería en la yglecia hospital desta ciudad y en sus remates puso dos campanas y una esquila que se repican en las funciones que en dicha casa se selevran a la Ymmaculada Comcepción y todas las beses que se da el biático a los enfermos, como también sirven para las funciones fúnebres de entierros y aniversarios que se hacen en dicha casa; y le consta al declarante la mucha caridad con que dicho Señor sirvió a los pobres enfermos en el tiempo que fue mayordomo de la referida casa, cuyo empleo admitió por solo su caridad, donando y haciendo gracia de los crecidos alcanses que resultaron de las cuentas del tiempo de su mayordomía a favor de los pobres de dicha casa, a la que antes y después de haver sido mayordomo ha mirado su piedad con expecial caridad y selo, contribuyendo a quanto se le pide para el socorro de dicha casa». 
se hallaban no sólo piezas propias de su servicio, sino otras como una caldera de azófar para la disciplina y dos jeringas que, junto con bacías o palanganas para lavar o hacer la barba de latón o de cobre y bacinillas de los mismos metales para recoger los excrementos y la orina, se utilizaban en la curación y el aseo de los pacientes. Tres servicios y un lebrillo de amasar de Castilla, otro servicio de Portugal y losa de Aveiro se adquirieron entre 1599 y 1602; y, a lo largo del siglo XVII, se continuaron comprando "servicios nuevos de España» (1642, 1650), «lebrillos blancos de España» y "tinajas de España», grandes y pequeñas, de procedencia seguramente sevillana. Los alfares de las islas proporcionaron "gánigos» o "gánegos», recipientes de barro moldeados a mano y sin torno que utilizaban los antiguos aborígenes canarios, mencionados en 1645, 1670, 1704, 1785 y 1798; jarritas de barro para tomar agua los enfermos y cántaras de Candelaria (Tenerife), también fabricadas a mano sin empleo del torno, compradas a partir de 1756; «cazuelas de Canaria» (1805); y orinales de la tierra (1757-1758). De barro de Los Sauces eran 19 orinales que se trajeron en 1802, dos a moneda por tierra y 17 a seis cuartos por mar. Cántaros, cazuelas y orinales breados eran impregnados con esta sustancia para impermeabilizarlos. Según detallan cuentas e inventarios, la losa y el menaje para el servicio de la casa y sus enfermos estaban integrados por platos y escudillas de barro o de barro blanco para comer los pobres, lebrillos (de cocina, de amasar, para lavar la carne, para hacer hostias), cazuelas y calderos de barro "para hacer de comer a los enfermos", escudillas y platos de pisa, servicios colorados, ollas para guardar las pasas o la unción, vidriadas para la manteca de ganado y de puerco, cazuelitas vidriadas para los huevos mejidos (1773-1781) y orzas «para el agua pasada» de los mismos (1774-1779), botijas, cántaras y tinajas de agua para la cocina, jarras para beber los enfermos, losa basta (orinales, lebrillos para sangrías y escudillas) y losa de la tierra para la cocina (1756-1757), escudillas grandes de piedra y otras blancas con platos (1796), cucharitas y cucharas de palo, de peltre (1761-1771) y de estaño (1796), «vorselanas» de barro para la cocina (1797), algunos contados vasos de vidrio (1773-1781), jarras, jarros y tazas de hojalata y latón para beber los enfermos ${ }^{132}$, y, para la cocina, foniles de lata... En peruleras y cántaros breados se conservaban las legumbres, mientras que el aceite y la miel de caña y de abeja se guardaban en botijas, las pasas en ollas y cestos, y las mebrilladas y otras conservas en cajas o cajetas de madera con sus tapas. En 1811 se hicieron una chocolatera, una cafetera para tisanas y cocimientos y una taza de latón para calentar ungüentos y unturas. De cobre eran los calderos de la cocina y del puchero, los calderitos "para quitar agua de la tinaja», la caldera para calentar el agua para los baños y de latón amarillo la caldera para cocimientos; de hierro, los garabatos para colgar la carne, el hacha para partirla (1743-1744), los asadores y las gradillas de los braseros y el sacador de fuego de la cocina (17741779); de cestería, el cesto con tapadera para traer el pan desde la casa de la panadera, los cestos de mano para la fruta, el «cesto lavandero» para la ropa (1704-1705) o

varro».

132 En 1799 se compraron «cuatro jarras de lata para vever los pobres por no encontrarse de 
el «balayo para el servicio de la casa» (1692-1694); y de madera, las cucharas de palo para la cocina y para comer los pobres (1746-1747) y las balsas para lavar la carne. El mobiliario de la casa estaba formado por cajas, arcas y baúles de madera para diferentes usos, como la caja «en que se echa la sera» (1643); la caja para guardar el pan y la harina, la «arquita chiquilla con su llave en que se echa la conserva» (1643); el arca de tres llaves perteneciente a la Junta de la Caridad ${ }^{133}$ o el baúl con la ropa de los fallecidos usada para las mortajas; «dos gavetas de palo» (1643), así como los toneles, cascos y pipas para pedir y recoger la limosna de vino por los lagares. Una fresquera (1800) o destiladera en forma de caja de madera cerrada por celosías, con su pestillera y piedra de destilar, servía para refrescar y purificar el agua, fabricada en 1784. Candiles, veloncillos y candeleros (1746-1747), alcuzas de barro y de piedra (1810), lámparas con vasos de aceite y hachas, como la «jachita» que se prendía en la cocina (1774-1779), se usaban para la iluminación. En los años de 1774-1779 se mantuvieron encendidas durante toda la noche cuatro lámparas de aceite en las dos salas de los enfermos y en los cuartos de unción y de los héticos; además de las velas de cebo que alumbraban en «los tránsitos de la casa» (1746-1747).

El servicio y el instrumental para atender a los pacientes se limitaba a bacinillas de latón y cobre y lebrillos de barro para enjuagar, lavar a los niños expósitos $^{134}$, sangrar o para el uso del cirujano; tijeras, jeringas ${ }^{135}$, ventosas, vejigas, pellejas o zaleas de cuero, vasos de vidrio "para echar medicamentos" y traer las purgas o para dar refrescos a los enfermos (1756-1757). La unción se conservaba en ollas de barro y para los ungüentos se hizo un cajón con sus filas y repartimientos de hojalata (1805). Los botiquines con el papel de las recetas se incorporaron tardíamente (1797). La limpieza de la casa se hacía con escobas de palma, "escobas de España» (1646) y "gánigos de fregar» (1798); mientras que para la higiene de los enfermos existían orinales, tinas para los baños (1738), cuya agua se calentaba con cargas de leña ${ }^{136}$, y juegos o palanganas de porcelana para lavarse (1800). En 1800 se labró una tina de castaño con tres arcos de hierro y con el mismo fin se compró un tonel en 1811, al que se le pusieron dos duelas (tablas convexas que formaban el contorno de la cuba). Fabricados en barro, los orinales se citan por primera vez en 1764-1765. A finales del siglo XVIII se construyeron cajitas de madera de pinsapo con la misma función ${ }^{137}$. Sillas con ruedas y carretones permitían la movilidad de impedidos e inválidos ${ }^{138}$. Con respecto a las camas de los enfermos, las cuentas de

133 Según consta en 1786, en la sala de acuerdos de la Junta de Caridad existía un arca de tres llaves con un letrero que la identificaba: «Arca de la real Junta de Caridad».

${ }^{134}$ En 1802 se compró un «librillo de barco» para lavar a los expósitos.

135 En 1640 se inventarían dos jeringas, una de ellas, «en casa de la señora Damiana Espino».

${ }^{136}$ En 1773 y 1778 se mencionan «la tina para los bańos de Juan José» y «la tina para la de María la de Tenerife».

${ }^{137}$ El carpintero Francisco José de la Madre de Dios construyó en 1797 ocho cajitas de orinales con un cajón de pinsapo y cuatro pequeños de la misma madera comprados a Ventura de Torres.

138 En el carretón fabricado en 1668-1669 para Francisco el Ciego se emplearon cuatro reales en clavos y unas chapas. 
los mayordomos mencionan tablas para barras de cama, hechas por el carpintero Baltasar Díaz en 1611, camas con "sus espaldares y pilaretes» en 1797 o la hechura de cuatro bancos de barra de cama y composición de otros cuatro en 1810. Tres reales de plata costaron la tabla y los clavos que necesitó el carpintero Carlos de los Reyes para hacer una cuna en 1743-1744. La falta de camas fue una constante y obligaba a traerlas desde las casas de los enfermos, como se hizo con la cama, colchón y cajita de una enferma que entró para curarse en 1802. Al igual que las paredes de las salas, catres, cunitas y cajas de orinales fueron pintados a principios del XIX por razones higiénicas ${ }^{139}$. Para sepultar a los fallecidos existían «tres ataúles de enterrar, dos chicos y uno grande», una azada para abrir las sepulturas y una espuerta, entregadas al ama en 1632. En 1784 Juan Montero se ocupó de componer la «caja de los difuntos»; y desde 1802 hay noticias de que se alquilaba una "caja mortuoria» con el mismo objeto ${ }^{140}$.

\section{ROPA DE CAMA Y DE VESTIR}

Según estableció la Junta de Caridad en el capítulo XIV de sus constituciones (1784), el mayordomo debía proveer de ropas al hospital

del modo que sea más cómodo y barato, o ya comprando los lienzos y géneros de la tierra, o ya de los extranjeros, o ya echando las telas de quenta del hospital [...] como también se yrá probeiendo de muebles y utencilios para el seruicio de los pobres, haziéndoles camas altas para no tenerlas en el suelo.

El informe redactado por los hermanos Diego Vargas Machuca y Dionisio O'Daly dos años después señala que a cada enfermo se le suministraba

un jergón que lleva 8 varas de lienzo brin a 4 de plata vara, dos sáuanas con 10 varas de coleta a 2 reales plata y una almohada de la misma de $1 \frac{1 / 2}{2}$ vara; con una manta que cuesta aquí 9 reales plata y los de unciones requieren dos mudas, así de los gergones como sávanas etca. La una mientras están con ellas y la otra después que salen para la combalesencia, fuera de otras enfermedades que obligan a mudar frequentemente.

Tal y como reflejan cuentas e inventarios, la ropa de cama estaba integrada por sábanas hechas con diferentes clases de lienzos y tejidos «de Francia» (1608) o del norte de Europa: angeo, brin, coleta, cotense, géneros que se adquirían a los mercaderes foráneos para confeccionar con ellos en la casa la ropa de blanca. Con frecuencia procedían de las almonedas o subastas verificadas en la plaza mayor y de los expolios de los bienes de difuntos, dadas de limosnas por los benefactores del hospi-

\footnotetext{
139 Véase nota 86.

140 En 1814-1815 se alquiló la caja mortuoria para las siete personas fallecidas en la casa.
} 
tal $^{141}$. Desde finales del siglo XviII, se empleó el «lienzo casero» o «de la tierra», tela con la que la Junta de Caridad mandó hacer 40 sábanas en 1808. En enero de 1812 se compraron 40 libras de lino, que, con una merma de 10 libras, sirvieron para tejer 75 varas (a 10 1/2 cuartos la vara) de lienzo casero. Con ellas se confeccionaron trece sábanas, dos pequeñas para expósitos y dos colchoncitos para los mismos. Las almohadas se enfundaban además con ruán (1618-1620), crea (1802), «listado» y «listadillo» (1808, 1811). En época más tardía (1811), se recurrió a la muselina para las sábanas más delicadas de los niños, al bramante para paños de cuna (1810) y a la saraza para las colchitas $(1808,1812)$. Junto con las «fresadas de España» y «cobertores de Castilla», desde fecha temprana aparecen las mantas de lana tejidas en la isla de El Hierro y sobre todo en la de Gran Canaria, conocidas como «mantas de Canaria» (1611, 1794), «mantas blancas de Canaria para cobertores de los enfermos» (16181620), fresadas ${ }^{142}$ y "colchas de Canaria» (1769-1771) o "colchas azules de Canaria» $(1800,1805)$. Según anotan los mayordomos, las mantas se gastaban rápidamente con los «muchos enfermos de unçión» y con algunos pobres mendigos que las hacían pedazos $(1675-1676)^{143}$. Cosidos o encordados con cuerdas o con hilo de vela (1795), los colchones se hacían con brin, angeo, «lienzo de dos anchos» (17741779) o «lienzo colchón» $(1802,1809)$ y se rellenaban con lana de la isla ${ }^{144}$, de la de El Hierro (recogida de limosna en aquella isla) o «lana de Canaria» (1639), paja y cargas de "pinillo» (1675-1676), forma usual en La Palma hasta no hace mucho. En 1615 se inventariaron 24 colchones, 12 sábanas, 30 cobertores y mantas y 10 almohadas; en 1639, según declaración del ama Francisca Pérez, 13 colchones de lana viejos y podridos, seis pedazos de mantas, dos sábanas, seis almohadas y otras seis almohadas viejas; y en 1648, 20 colchones que usaban los mendigantes, enfermos y sacristán. Los jergones se protegían del frío y la humedad con "pellejas» (1785) o «zaleas» de cuero de oveja curtido o de paño de tela doble de lienzo casero o lienzo portugués, colocadas transversalmente debajo de las sábanas de los pacientes y en las cunas de los niños. Esteras y «esteritas» se ponían igualmente bajo las camas de los

141 En 1603 se inventariaron seis fresadas «de España», doce mantas de Canaria, once sábanas y otras tantas almohadas, a las que se fueron agregando en los ańos siguientes de 1604, 1605, 1607 y 1608 una manta nueva de El Hierro, 14 sábanas de angeo y cinco mantas de Canaria que dio o que se hicieron en tiempos del mayordomo Andrés Maldonado, seis de ellas de seis varas cada una; dos colchones, tres sábanas, una barra de cama y un cobertor comprados en la almoneda de Soriano; cuatro mantas de Canaria aportadas como limosna por el capitán Juan del Valle en noviembre de 1607; ocho sábanas «de Fransia» donadas por el clérigo Vicente Rodríguez, entregadas en 1608 al ama por el capitán Andrés Maldonado; seis sábanas, dádiva del mercader Francisco García en septiembre de 1608; seis cobertores blancos de Castilla, limosna del capitán Andrés Maldonado en marzo de 1608; una manta que dio el capitán Gaspar Vandeval en abril de 1609; y otros seis cobertores blancos, regalo del capitán García de las Muñecas.

142 En 1639 envió doce fresadas «una devota de Canaria para la casa, que no tenía ninguna, a 10 reales cada vna».

143 En 1675-1676 se compraron 12 mantas a 11 reales "por auerse gastado con los muchos enfermos de unçión y Juan Espejo que las haze pedasos». Pobre mendigante, Juan Espejo falleció con 40 años de edad en junio del año siguiente.

${ }^{144}$ En 1618-1620 se compraron al doctor Escudero dos quintales de lana para colchones. 
uncionados (1703-1704), enfermos y amas de cría $(1787,1798)$. Con el lino hilado en la casa por las amas se hacían cuerdas para los colchones (1785), se remendaban (1639) y se cosía la ropa. Pañuelos (de rúan, de lienzo casero), servilletas para las comidas, pañitos y cabezales para las camas contribuían a la higiene y limpieza de los enfermos. En 1811 los pacientes estrenaron paños y servilletas de muselina, que hasta entonces "nunca las había habido», destinadas a guardar "su pan y por aseo». Para poner a «los pobres que entran desnudos» se confeccionó además en 1796 una camisa de coleta. La ropa para vestir y cubrir a los niños expósitos incluía diversas prendas hechas con diferentes clases de lienzos, algodón y lana: camisas y camisitas de algodón (1639), coleta, crea, lienzo fino (1774-1779), lienzo portugués ${ }^{145}$ y muselina (1809); sobrecobijas de lienzo fino y tapiz de lana (1774-1779); mantillas de paño azul de Canaria (1647) y algodón (1800); fajas de bayeta (1799), bayeta amarilla (1802), crea y muselina (1810); tiras de las fajas de bayeta, coleta, lienzo gordo, lienzo portugués (1809) y muselina (1810); petos de bayeta; refajos de coleta (1802), faldellines de "calimanco de color» (1774-1779), pañitos de cabeza y pańales o «culeros»... En su ceremonia de bautismo, los recién nacidos eran ataviados con camisas, faldellines, cobijas y mantillas elaboradas con lienzos finos y sedas, traje o conjunto de ceremonia que, por su continuo uso, fue necesario renovar cada cierto tiempo. Con "garipola azul», bretaña y lienzo delgado se confeccionó una cobija, sobrecobija y camisilla de bautismo en 1743-1744. Años después, en 1764-1765, el presbítero don Francisco Dionisio Volcán y Monterrey dio de limosna durante su mayordomía una mantilla de raso azul, un faldellín de raso listado, otro de garipola encarnado y otro blanco, una toalla con puntas, una fajuela y una camisita fina para llevar a los niños a bautizar. En 1810 se hicieron nuevas vestimentas de bautismo con dos camisitas, una sobrecobija y un faldellín de holán con encaje y cintas. Con sabanillas se los amortajaba para enterrarlos.

Recibido: 04-04-2019. Aceptado: 11-04-2019

145 En 1799 se hicieron 32 camisitas para los niños con lienzo portugués, al igual que las tiras de las fajas y tres fajas, "por no encontrarse vayeta de ninguna especie», todo hechura de limosna. 


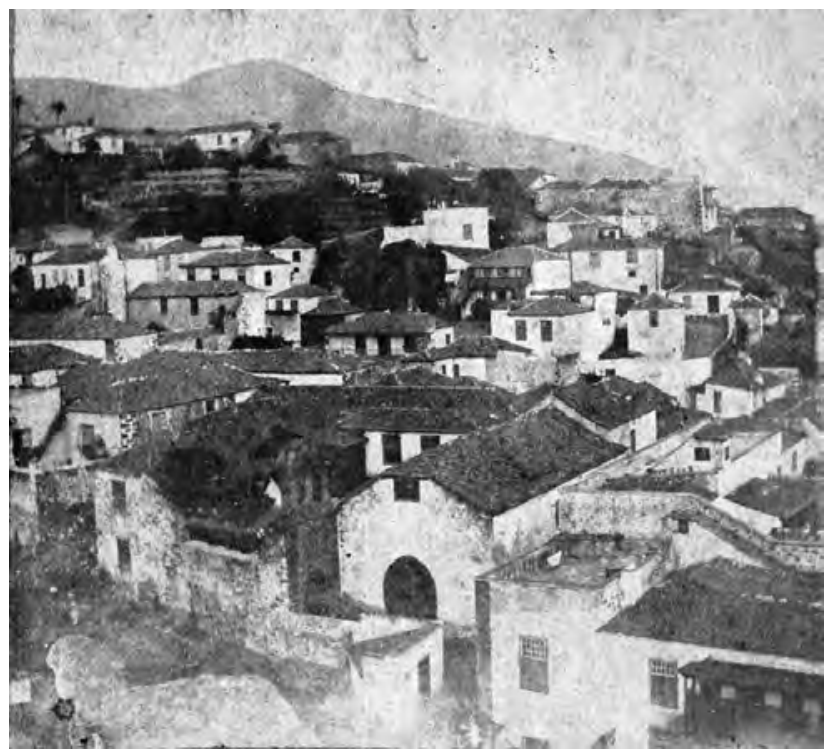

Fig. 1. Vista de la antigua casa-hospital de Nuestra Señora de los Dolores, con la iglesia (actual "Teatro Chico») y la puerta-campanario que daba acceso al patio o claustro. Santa Cruz de La Palma, finales del siglo XIX.

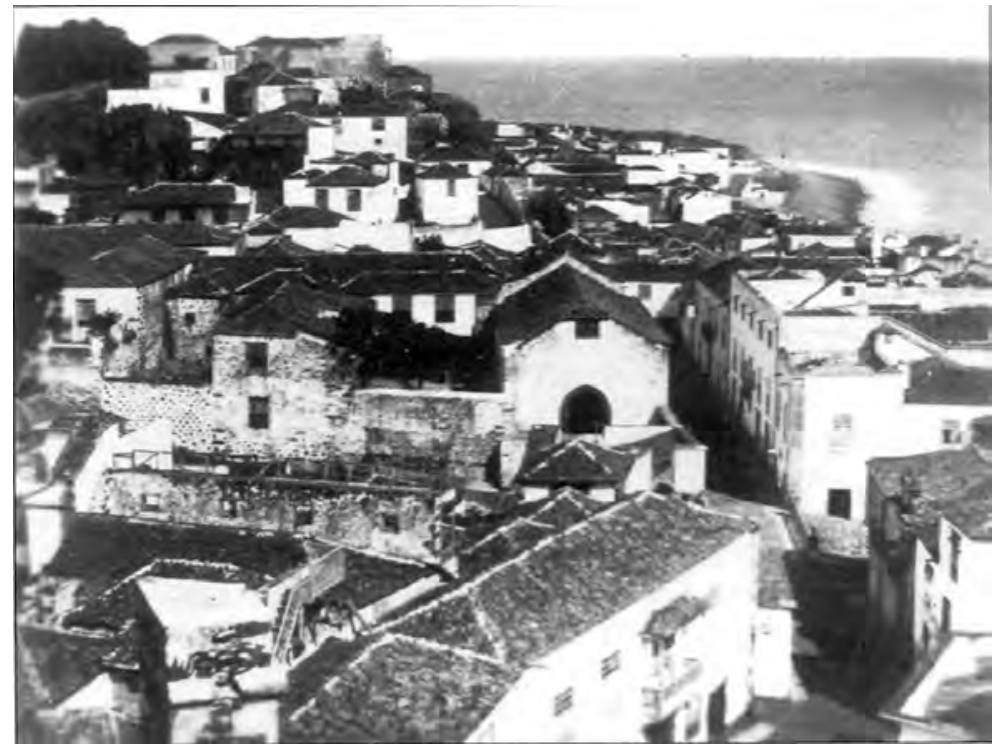

Fig. 2. Vista de la antigua casa-hospital de Nuestra Seńora de los Dolores, con la iglesia, el patio o claustro, el traspatio y el cuarto hacia el barranco. Santa Cruz de La Palma, c. 1860-1870. 


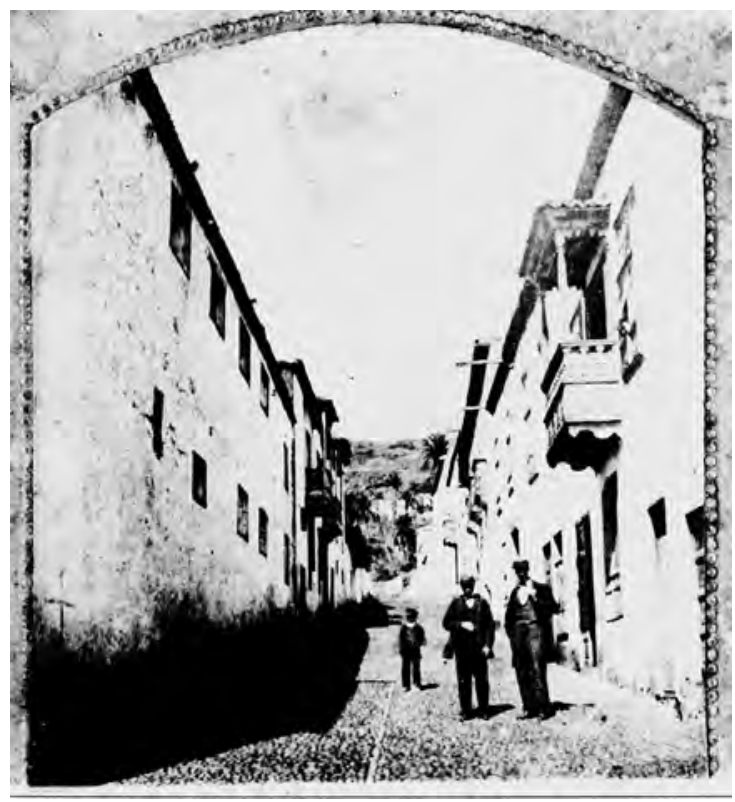

Fig. 3. Antigua "calle de la Cuna». En el lado izquierdo, la fachada principal de la casa-hospital. Santa Cruz de La Palma, 1850.

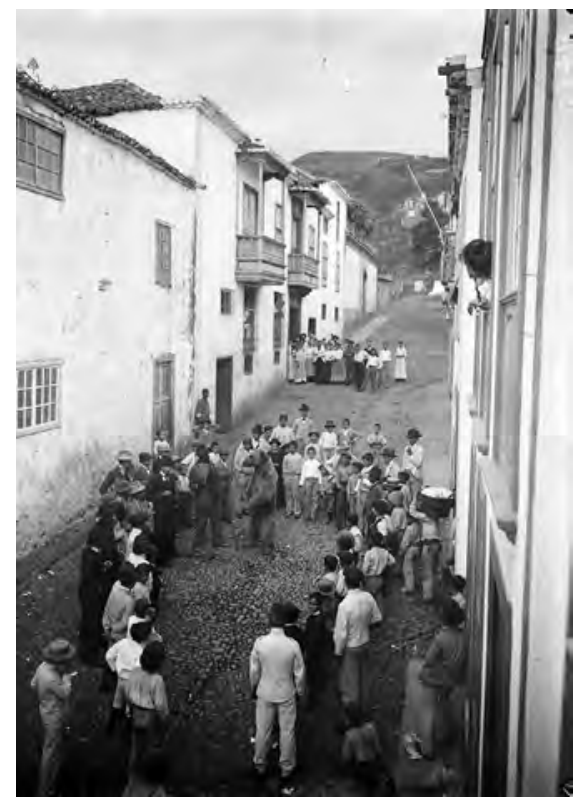

Fig. 4. Antigua "calle de la Cuna». Vista, en el lado izquierdo, de la antigua casa-hospital y la casa Fierro. Santa Cruz de La Palma, 1901. 